\title{
Long-term Effectiveness of a Smartphone App Combined With a Smart Band on Weight Loss, Physical Activity, and Caloric Intake in a Population With Overweight and Obesity (Evident 3 Study): Randomized Controlled Trial
}

Cristina Lugones-Sanchez ${ }^{1}$, NP; Jose I Recio-Rodriguez ${ }^{1,2}$, PhD; Cristina Agudo-Conde ${ }^{1}$, MSc; Irene Repiso-Gento ${ }^{3}$, MD; Esther G Adalia ${ }^{4}$, MSc; José Ignacio Ramirez-Manent ${ }^{5,6}, \mathrm{MD}, \mathrm{PhD}$; Maria Antonia Sanchez-Calavera ${ }^{7,8}$, MD, $\mathrm{PhD}$; Emiliano Rodriguez-Sanchez ${ }^{1,9}, \mathrm{MD}, \mathrm{PhD}$; Manuel A Gomez-Marcos ${ }^{1,9^{*}}, \mathrm{MD}, \mathrm{PhD}$; Luis Garcia-Ortiz ${ }^{1,10^{*}}, \mathrm{MD}$, $\mathrm{PhD}$; EVIDENT 3 Investigators ${ }^{11^{*}}$

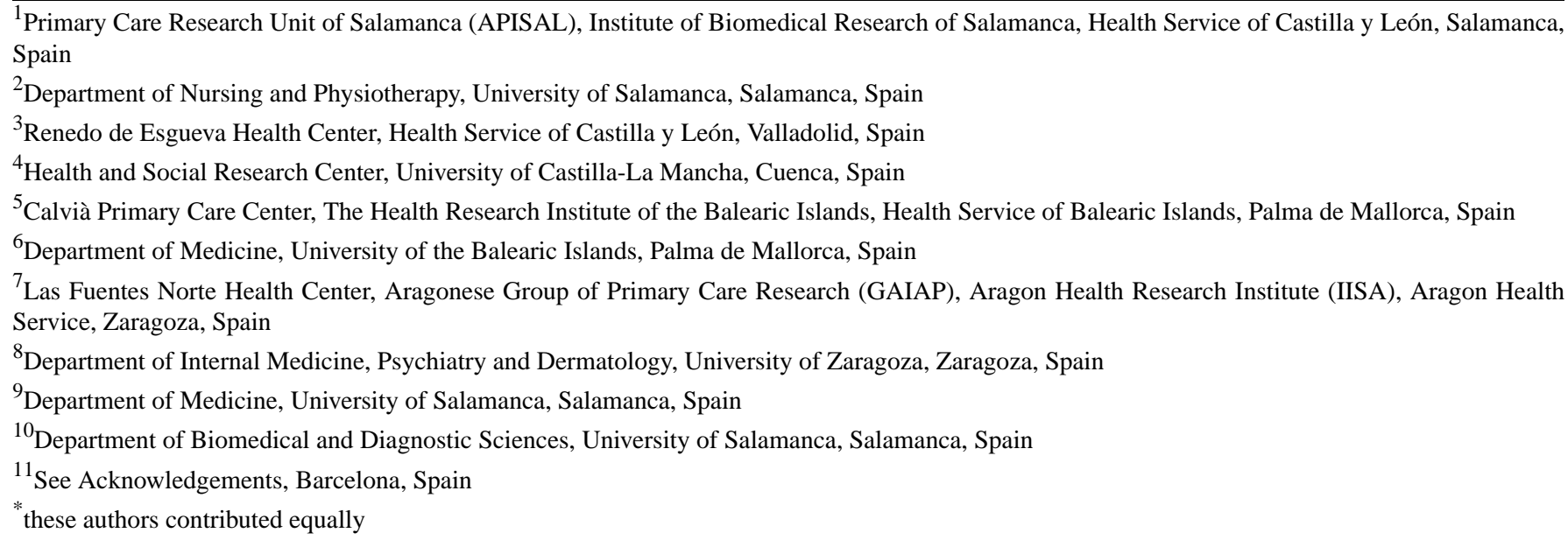

\section{Corresponding Author:}

Cristina Lugones-Sanchez, NP

Primary Care Research Unit of Salamanca (APISAL)

Institute of Biomedical Research of Salamanca

Health Service of Castilla y León

Avda Portugal 83, 2nd Fl.

Salamanca, 37005

Spain

Phone: 34923291100 ext 54750

Email: crislugsa@gmail.com

\section{Abstract}

Background: Multicomponent mobile health approaches can improve lifestyle intervention results, although little is known about their long-term effectiveness.

Objective: This study aims to evaluate the long-term effectiveness (12 months) of a multicomponent mobile health intervention - combining a smartphone app, an activity tracker wristband, and brief counseling, compared with a brief counseling group only_on weight loss and improving body composition, physical activity, and caloric intake in Spanish sedentary adults with overweight or obesity.

Methods: We conducted a randomized controlled, multicenter clinical trial (Evident 3). A total of 650 participants were recruited from 5 primary care centers, with 318 participants in the intervention group (IG) and 332 in the control group (CG). All participants were briefly counseled about a healthy diet and physical activity at the baseline visit. For the 3-month intervention period, the IG received training to use the app to promote healthy lifestyles and the smart band (Mi Band 2, Xiaomi). All measurements were performed at baseline and at 3 and 12 months. Physical activity was measured using the International Physical Activity 
Questionnaire-Short Form. Nutritional habits were assessed using the Food Frequency Questionnaire and Adherence to Mediterranean diet questionnaire.

Results: Of the 650 participants included, $563(86.6 \%)$ completed the 3-month visit and $443(68.2 \%)$ completed the 12-month visit. After 12 months, the IG showed net differences in weight $(-0.26,95 \% \mathrm{CI}-1.21$ to $0.70 \mathrm{~kg} ; P=.02), \mathrm{BMI}(-0.06,95 \% \mathrm{CI}$ -0.41 to 0.28 points; $P=.01)$, waist-height ratio $(-0.25,95 \% \mathrm{CI}-0.94$ to $0.44 ; P=.03)$, body adiposity index $(-0.33,95 \% \mathrm{CI}-0.77$ to $0.11 ; P=.03)$, waist circumference $(-0.48,95 \% \mathrm{CI}-1.62$ to $0.66 \mathrm{~cm}, P=.04)$ and hip circumference $(-0.69,95 \% \mathrm{CI}-1.62$ to $0.25 \mathrm{~cm} ; P=.03$ ). Both groups lowered daily caloric intake and increased adherence to the Mediterranean diet, with no differences between the groups. The IG increased light physical activity time $(32.6,95 \% \mathrm{CI}-30.3$ to $95.04 \mathrm{~min} /$ week; $P=.02)$ compared with the CG. Analyses by subgroup showed changes in body composition variables in women, people aged $>50$ years, and married people.

Conclusions: The low-intensity intervention of the Evident 3 study showed, in the IG, benefits in weight loss, some body composition variables, and time spent in light physical activity compared with the CG at 3 months, but once the devices were collected, the downward trend was not maintained at the 12-month follow-up. No differences in nutritional outcomes were observed between the groups.

Trial Registration: ClinicalTrials.gov NCT03175614; https://clinicaltrials.gov/ct2/show/NCT03175614

International Registered Report Identifier (IRRID)： RR2-10.1097/MD.0000000000009633

(J Med Internet Res 2022;24(2):e30416) doi: 10.2196/30416

\section{KEYWORDS}

mobile app; telemedicine; eHealth; weight control; exercise; obesity; mobile phone

\section{Introduction}

\section{Background}

The combination of excess body weight and physical inactivity contributes to global mortality [1,2] and to a shorter healthy life expectancy [3]. Moreover, both are associated with a major risk for serious chronic diseases, including type 2 diabetes and cardiovascular diseases, as well as increasing cardiovascular risk factors [4]. Such conditions may impact individual quality of life and well-being while increasing the burden on the health system [5]. Several strategies have been implemented to tackle obesity, mainly focusing on changing lifestyles. In general, weight loss interventions aim to increase physical activity, reduce daily energy intake, improve diet or nutritional habits, and achieve psychological changes [6]. Owing to the complex nature of obesity, multicomponent interventions, capable of addressing various aspects related to its causes, are shown to be more effective in reducing cardiovascular risk factors [7] and body weight [8]. However, finding accessible and cost-effective multicomponent strategies that promote healthy lifestyles over time is challenging.

\section{Mobile Health}

Mobile health (mHealth) approaches, which are defined as the use of mobile wireless technologies for health [9], could optimize these efforts as portable and flexible tools, as well as improve the follow-up and feedback by registering health information [10] and provide efficient health management assistance for patients [11]. Specifically, some reviews suggested that mHealth could be more effective in losing weight than traditional approaches [12,13]. Among mHealth tools, smartphones are positioned as the most effective approach to achieve weight management [14], showing the most beneficial effects in the short term [15] ( $\leq 6$ months). However, mobile phone intervention reports modest improvements in other lifestyles such as physical activity [16] or changes in biomarkers
[13], highlighting the need to complement the intervention with other tools. Along these lines, wearable devices have garnered attention in improving physical activity and reducing sedentary lifestyle. Pedometer-based interventions have been widely explored [17], but the constant evolution of these tools requires the inclusion of emerging electronic devices [18]. Activity tracker wristbands, also called "smart bands," have shown their validity and reliability in measuring physical activity outcomes [19] (eg, steps, kilometer walked, and intensity). Furthermore, a recent systematic review found that these device-based interventions are effective for increasing physical activity among chronic disease populations [20], making activity tracker wristbands a good option for inclusion in lifestyle interventions, as wearable activity trackers have the potential to increase physical activity participation [21]. However, wearable activity trackers alone may not be sufficient to achieve the expected lifestyle changes [22], so their inclusion in mHealth multicomponent obesity interventions, which appears to be more effective than app interventions alone [23], could be a beneficial strategy to obtain positive results in diet, physical activity, or other health variables [24,25]. In addition, self-monitoring in digital health interventions is associated with greater weight loss [26], so the use of both approaches could produce better weight outcomes.

Despite these promising results, the evidence for long-term efficacy is still limited, revealing that more evidence of effectiveness over long follow-up periods is required [27]. A systematic review showed that wearable devices might improve long-term physical activity and weight loss outcomes, although a comparison with traditional methods did not show clear benefits [28]. A similar situation exists with regard to multicomponent interventions with wearables, which may provide a strategy to improve long-term weight loss [29] despite the limited data on its effectiveness. 


\section{Objectives}

Previously, the Evident 2 study evaluated the effect of adding an app (Evident 2) to a standardized intervention designed to improve adherence to the Mediterranean diet and increase physical activity in the general population [30]. The Evident 3 study aimed to evaluate the long-term effectiveness (12 months) of a multicomponent mHealth intervention-combining a later version of the smartphone app (Evident 3) and a smart band, compared with a brief counseling-only group — on body weight loss, improving body composition, increasing time spent in physical activity, and decreasing caloric intake in Spanish sedentary adults with overweight and obesity. The short-term study results (3 months) related to body composition have already been published [31].

\section{Methods}

\section{Design and Setting}

A multicenter, randomized controlled clinical trial with 2 parallel groups was conducted in a primary care setting (Evident 3 study). The Primary Care Research Unit of Salamanca (APISAL) at the Biomedical Research Institute of Salamanca (IBSAL) coordinated the project in 5 health centers located in Spain from the Network for Preventive Activity and Health Promotion (REDIAPP; Salamanca, Valladolid, Cuenca, Palma de Mallorca, and Zaragoza). The main aim of the study was to evaluate the effect of the intervention on weight loss in participants with overweight and obesity [32] (ClinicalTrials.gov NCT03175614). Between June 2017 and June 2020, evaluations were made at baseline and after the completion of 3 and 12 months. The results presented in this paper correspond to the long-term effect (12 months) of the 3-month mHealth intervention on the primary outcome (weight loss) and secondary outcomes related to physical activity and diet.

\section{Study Population}

The participants were selected by random sampling among patients who attended a consultation with their primary care provider in each participating center. The inclusion criteria were age between 20 and 65 years, a BMI between $27.5 \mathrm{~kg} / \mathrm{m}^{2}$ and $40 \mathrm{~kg} / \mathrm{m}^{2}$, classified as sedentary $(20$ minutes of vigorous-intensity activity $\leq 3$ times per week; 30 minutes of moderate-intensity activity $\leq 5$ times per week; or any combination of moderate and vigorous activity $\leq 5$ times per week [33]), agreement to participate in the study, and signing the informed consent document. A detailed description of the exclusion criteria can be found elsewhere [32].

\section{Sample Size}

The sample size calculation was performed for the primary study endpoint of weight loss at 12 months. Accepting an $\alpha$ risk of .05 and a $\beta$ risk of .20 , with an SD of $12 \mathrm{~kg}$, estimated in participants from the Evident 2 study [30], 592 participants would be needed (296 per group) to detect a decrease in weight of $\geq 3 \mathrm{~kg}$ [34] in the intervention group (IG) versus the control group (CG), considering a $15 \%$ loss to follow-up. This effect size represents a $3 \%$ to $5 \%$ difference between groups, which should produce clinically relevant health benefits [35].

\section{Randomization}

Participants were randomly assigned to either the IG or the CG after the baseline visit and provided informed consent. The allocation sequence was generated in a 1:1 ratio using the Epidat (version 4.2; Xunta de Galicia) software package [36] by an independent researcher and concealed until the group was assigned. Owing to the nature of the study, the intervention could not be blinded to the participants.

\section{Procedures}

Each participant completed an initial visit and 2 follow-up visits at 3 and 12 months after randomization (Figure 1). They did not receive any compensation for the study or visit completion. Data from the visits were collected by a research nurse on a paper-based Case Report Form and recorded after the visit on the study website. The IG completed an additional appointment 7 days from the baseline visit to explain the use of the smartphone app and set it with the participant's data. The researcher who carried out the additional appointment was different from the researcher who collected the data of the visits. 
Figure 1. Flowchart of the Evident 3 study.

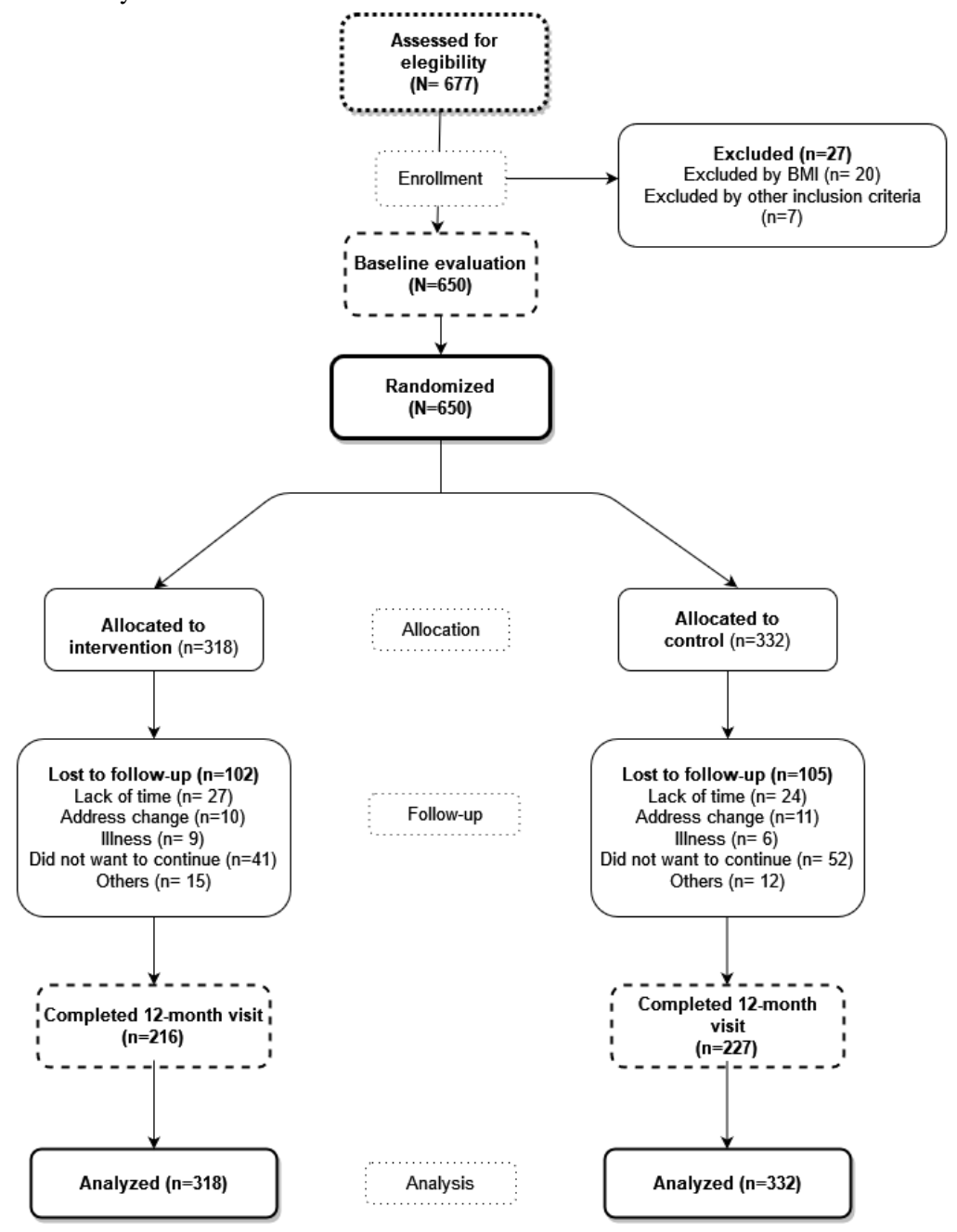

\section{Primary and Secondary Outcomes}

\section{Overview}

The primary outcome was weight loss $(\mathrm{kg})$. The secondary outcomes included changes in physical activity (min/week), caloric intake (kcal/day), adherence to the Mediterranean diet (points), and changes in body composition (anthropometric indexes). All outcomes were measured at baseline and at 3 and 12 months after randomization.

\section{Weight Loss}

Body weight was measured twice to the nearest $0.1 \mathrm{~kg}$, with the participant barefoot and wearing light clothing, using a homologated electronic balance (Scale 7830; Soehnle Professional $\mathrm{GmbH} \& \mathrm{Co}$ ). Height was measured with the participant barefoot in the standing position using a portable system (Seca 222; Medical scale and measurement system). BMI was calculated by dividing weight $(\mathrm{kg})$ by height squared $\left(\mathrm{m}^{2}\right)$. Waist circumference was measured twice on bare skin, using a flexible tape parallel to the floor, at the level of the upper border of the iliac crest, with the participant standing and after inspiration, following the recommendations of the Spanish Society for the Study of Obesity [37]. Hip circumference was similarly measured at the level of the trochanters over the underwear.
In addition, anthropometric indices were estimated to evaluate body composition changes:

Waist-height ratio $=$

$$
\text { WC / Height (1) }
$$

Body adiposity index $=$

$$
\left[\mathrm{HC} /\left(\text { Height }^{1.5}\right)\right]-18 \text { (2) }
$$

Waist-hip ratio $=$

WC / HC (3)

Body shape index [38] =

$$
\mathrm{WC} /\left[\left(\mathrm{BMI}^{0.666}\right) \times\left(\text { Height }^{0.5}\right)\right]
$$

Body roundness index [39] =

$$
\begin{aligned}
& 364.2-365.5 \times \sqrt{ }\left\{1-[\mathrm{WC} /(2 \times 3.1416)]^{2} /(0.5 \times\right. \\
& \text { Height } \left.)^{2}\right\} \mathbf{( 5 )}
\end{aligned}
$$

\section{Physical Activity}

Physical activity was assessed using the short version of the International Physical Activity Questionnaire-Short Form (IPAQ-SF) [40]. The IPAQ-SF is a self-reported questionnaire that evaluates sitting and active time in the last 7 days through 7 questions. The categories consisted of walking, moderate-intensity activity, and vigorous-intensity activity, according to the energy expenditure estimated for each of them: 
3.3, 4.0, and 8.0 metabolic equivalents (METs), respectively; 1 MET being the amount of oxygen consumed while sitting at rest [41]. Thus, the IPAQ-SF enables METs-minutes per week to be calculated, and participants were stratified into 3 activity levels (low, intermediate, and high).

\section{Nutritional Habits}

Caloric intake (kcal/day) and dietary habits of participants were evaluated using a semiquantitative Food Frequency Questionnaire previously validated in the Spanish population [42]. The frequency options are divided into 9 intake categories, ranging from never to $>6$ servings per day. Food Frequency Questionnaire data were used to estimate the daily intake of macro- and micronutrients and the mean kcal/day.

Adherence to the Mediterranean diet was assessed using the validated 14-point Mediterranean Diet Adherence Screener [43] developed by the prevention with Mediterranean diet study group, which comprises 12 questions on food consumption frequency and 2 questions on food intake habits. Each question was scored as 0 or 1 , and the total score ranged from 0 to 14 . A total score of 9 points or higher indicated adequate adherence.

\section{Adherence to Self-monitoring on the Smartphone App}

Adherence to self-monitoring on the smartphone app was assessed by the number of days that the participants logged into the app and recorded any dish or food. Records were classified into 4 categories: 0 days, 1 to 30 days, 31 to 60 days, and $>60$ days. Participants who used the app for $>60$ days during the 3 months that they had the app were classified as sufficiently adherent, whereas $\leq 60$ days of use was classified as having low adherence.

\section{Other Variables}

\section{Sociodemographic Variables}

Data on age, sex, marital status, educational level, and occupation were collected at the time of inclusion in the study.

\section{Peripheral Blood Pressure}

Three measurements of systolic and diastolic blood pressure were performed using the average of the last 2 measurements with a validated Omron M10-IT model sphygmomanometer (Omron Healthcare). The measurements were made on both arms, with the participant seated, after at least 5 minutes of rest with an appropriately sized cuff, following the recommendations of the European Society of Hypertension [44].

\section{Smoking Status}

This was assessed through a questionnaire of 4 standard questions adapted from the World Health Organization monitoring of trends and determinants in cardiovascular disease study [45]. Study participants were classified as current smokers, former smokers (>1 year without smoking), or nonsmokers.

\section{Intervention}

A detailed description of brief counseling and specific intervention has been published in the study protocol [32]. All the intervention materials were provided in Spanish.

\section{Standard Counseling (CG and IG)}

A trained nurse at each primary health center, who was not involved in other aspects of the study, gave 5 minutes of lifestyle counseling to both groups (CG and IG) before randomization, focusing on physical activity and diet in compliance with the international recommendations for the general population. The health benefits of physical activity were explained as well as the recommendation to complete at least 30 minutes of moderate activity 5 days a week, or 20 minutes of vigorous activity 3 days a week. Counseling on food was in compliance with the plate method [46], in which a plate is divided into 4 parts: half the plate for salad or vegetables, one-quarter for proteins (white meat preferred over red meat), and the final quarter for carbohydrates. In addition, a medium-sized piece of fruit and a skimmed dairy product should be consumed for dessert. This advice enhanced the intake of healthy food, according to the Mediterranean diet pattern, and daily caloric intake goals were not included. No reinforcement of counseling was offered at any other study visit or between the 3-and 12-month visits.

\section{Specific Intervention (IG)}

The IG received a low-intensity intervention consisting of a smartphone with the EVIDENT 3 app (Samsung Galaxy J3) and a smart band (Xiaomi Mi Band 2) for 3 months, corresponding to the length of the intervention, without any additional reinforcement or counseling by the investigators throughout the study. Participants were trained at another 15-minute visit scheduled 7 days after the baseline visit in the use of the app (EVIDENT 3 app [record entry no. 00/2017/2438]) specifically designed for the study by CGB Computer Company and APISAL, as well as the use of the smart band, instructing them to use both tools daily.

During this visit, the app was configured with each participant's data (sex, age, weight, and height). It was designed to allow full daily self-monitoring of food intake (Figure 2) and automatically record physical activity through the smart band, which was configured to synchronize with the app. Participants entered their food intake daily by selecting dishes and foods from the app menu and indicating the portion size. Food composition data were collected from the Spanish Food Composition Database [47], developed by Spanish Food Composition Database Network and Spanish Agency for Food Safety and Nutrition. Once all the daily information is collected, the app integrates the data to create personalized healthy food recommendations based on the Mediterranean diet pattern and specific targets for daily calorie intake that would lead to weight loss. The app displays the amount of calories recorded (Figure 2) and a bar that changes color (green, yellow, or red) according to the level set. It was configured to achieve a hypocaloric diet, calculating the upper limit (the red line) by adding, according to age and sex, the basal metabolic rate, diet-induced thermogenesis, and estimated energy expenditure for sedentary activities. The lower limit (the black line) was $85 \%$ of the calories calculated, and below this, the bar appeared in green; between the red and black lines, it appeared in yellow; and above the red line, it appeared in red. The participant was able to consult the app for these recommendations as well as information about caloric intake changes and macronutrient 
distribution (carbohydrates, proteins, and unsaturated and saturated fats). The smart band was set to congratulate the user when reaching 10,000 steps/day, and the app displayed this step recommendation in the goals section. Behavioral strategies were included in the mHealth intervention to enhance self-efficacy using self-monitoring, goal-setting, and positive reinforcement. At the 3-month visit, participants returned the intervention tools to the researchers. Thereafter, participants did not have access to the intervention devices and were advised not to use other digital tools for weight loss until the end of the study. All the information generated by the app was duly analyzed and entered into the database. In addition, once the tools were returned, monthly mean daily steps and activity minutes were collected for the last 2 of the 3 months of the intervention from the Mi Fit app (Xiaomi) to assess whether the smart band was worn.

Figure 2. Evident 3 app screenshots.
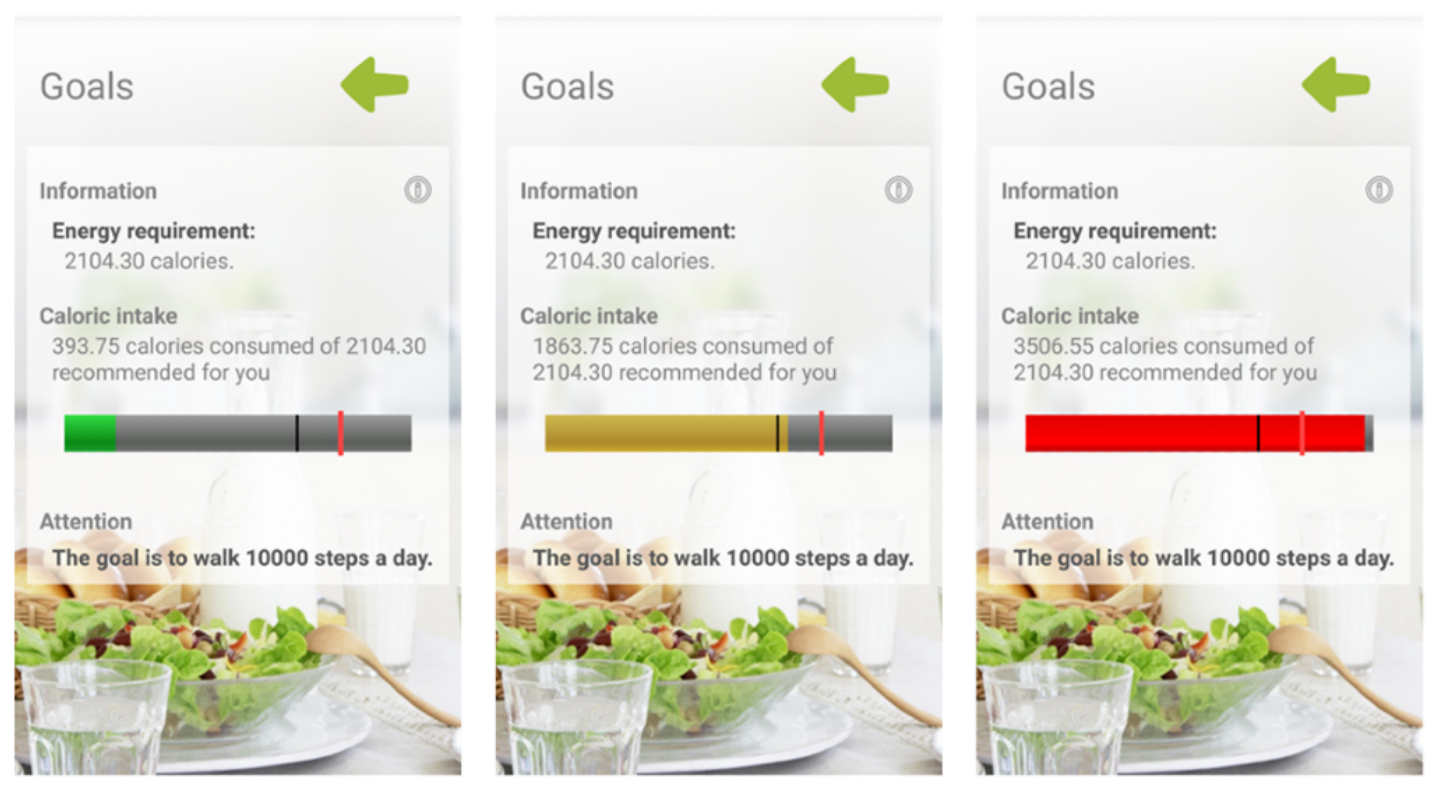

\section{Blinding Strategy}

The researcher who carried out the specific intervention was different from the person responsible for the assessment and the standard counseling; both were kept blinded throughout the study, as was the investigator who conducted the data analysis. Owing to the nature of the study, the participants could not be blinded. To prevent contamination between groups, in the follow-up visits (3 and 12 months), only the study variables were evaluated, but no advice or reinforcement was provided In addition, the app was not available for download on the internet or anywhere until the end of the study, so the CG was not able to make use of it in any way. During the follow-up visits, participants were instructed not to use other digital health technologies.

\section{Statistical Analysis}

Baseline characteristics of the study population were expressed as mean and SD for quantitative variables and as frequency distributions for categorical variables. Student $t$ test (2-tailed), chi-square test, and Fisher exact test were used to determine differences in baseline characteristics between the IG and CG. Analyses of the results were performed on an intention-to-treat basis. Paired Student $t$ test or McNemar test was applied to assess changes within the same group. To analyze the effect of the intervention, in the follow-up for primary and secondary endpoints, we performed several multivariate analyses of the variance of repeated measures using the general linear model, comparing the changes observed between the IG and CG in the analyzed variables, first unadjusted and then adjusted for age and sex.

We performed a subanalysis by multivariate analysis of the variance of repeated measures of the intervention effect in primary and secondary outcomes stratified by sex (men and women), age ( $<50$ years and $\geq 50$ years), and marital status (married, single, or others).

The contrast in the hypotheses established an $\alpha$ value of .05. The data were analyzed using SPSS Statistics software (version 26.0; IBM Corporation).

\section{Ethical Considerations}

The study was approved by the clinical research ethics committee of the Health Area of Salamanca in April 2016. In addition, the study was approved by the ethics committees of the 4 collaborating centers: Aragón, Castilla-la Mancha, Baleares, and Valladolid Oeste. All procedures were performed in accordance with the ethical standards of the institutional research committee and the 2013 Declaration of Helsinki [48]. All participants signed written informed consent documents before participation in the study. The trial was registered at ClinicalTrials.gov with identifier NCT03175614 on May 31, 2017. 


\section{Results}

\section{Baseline Characteristics of the Participants and Follow-up}

Of the 650 participants who completed the baseline visit, 563 (86.6\%) completed the 3-month visit and $443(68.2 \%)$ completed the 12-month visit. There were 207 (207/650, 31.8\%) participants who dropped out of the study, 32.1\% (102/318) in the IG and 31.6\% (105/332) in the CG. Participants assigned to each group and the reasons for withdrawal from the trial may be consulted in Figure 1.

The clinical and sociodemographic baseline characteristics of the 650 participants are presented in Table 1 . The mean age of the entire sample was 48.31 (SD 9.67) years, with a mean BMI of 33.0 (SD 3.48) kg/m². In addition, $68.5 \%$ (445/650) of participants were women, $68.3 \%$ (444/650) were married, and $46.8 \%(304 / 650)$ were aged $\geq 50$ years. No differences were observed between the study groups at baseline.

The comparison between the baseline characteristics of the 207 participants who dropped out and those who completed the study are shown in Multimedia Appendix 1. It should be noted that those who dropped out were younger ( 46.3 vs 49.2 years) and had a higher weight (93.3 vs $90.2 \mathrm{~kg}$ ) and BMI (33.6 vs $32.7 \mathrm{~kg} / \mathrm{m}^{2}$ ), with no difference in the rest of the variables analyzed. 
Table 1. Baseline characteristics of study participants.

\begin{tabular}{|c|c|c|}
\hline Characteristics & Intervention $(\mathrm{n}=318)$ & Control $(n=332)$ \\
\hline \multicolumn{3}{|l|}{ Age (years) } \\
\hline Value, mean (SD) & $47.7(10.1)$ & $48.9(9.2)$ \\
\hline$<50, \mathrm{n}(\%)$ & $178(56)$ & $168(50.6)$ \\
\hline$>50, \mathrm{n}(\%)$ & $140(44)$ & $164(49.4)$ \\
\hline \multicolumn{3}{|l|}{$\operatorname{Sex}, \mathbf{n}(\%)$} \\
\hline Men & $104(32.7)$ & $101(30.4)$ \\
\hline Women & $214(67.3)$ & $231(69.6)$ \\
\hline \multicolumn{3}{|l|}{ Marital status, n (\%) } \\
\hline Single & $60(18.9)$ & $74(22.3)$ \\
\hline Married & $222(69.8)$ & $222(66.9)$ \\
\hline Separated & $31(9.7)$ & $30(9)$ \\
\hline Widower & $5(1.6)$ & $6(1.8)$ \\
\hline \multicolumn{3}{|l|}{ Employment status, n (\%) } \\
\hline Works outside of home & $232(72.9)$ & $249(75.1)$ \\
\hline Homemaker & $22(6.9)$ & $21(6.3)$ \\
\hline Retired & $22(6.9)$ & $19(5.7)$ \\
\hline Student & $9(2.8)$ & $5(1.5)$ \\
\hline Unemployed & $33(10.4)$ & $38(11.4)$ \\
\hline \multicolumn{3}{|l|}{ Educational level, n (\%) } \\
\hline University studies & $122(38.5)$ & $134(40.5)$ \\
\hline Middle or high school & $158(48.9)$ & $152(45.9)$ \\
\hline Elementary school & $37(11.7)$ & 45 (13.6) \\
\hline \multicolumn{3}{|l|}{ Clinical variables, mean (SD) } \\
\hline Weight $(\mathrm{kg})$ & $91.4(14.8)$ & $91.1(14.8)$ \\
\hline BMI $\left(\mathrm{kg} / \mathrm{m}^{2}\right)$ & $33.1(3.4)$ & $33.0(3.6)$ \\
\hline Waist circumference $(\mathrm{cm})$ & $107.4(12.9)$ & $107.4(10.7)$ \\
\hline Systolic blood pressure $(\mathrm{mm} \mathrm{Hg})$ & $119(15)$ & $120(16)$ \\
\hline Diastolic blood pressure $(\mathrm{mm} \mathrm{Hg})$ & $79(9)$ & $81(10)$ \\
\hline Heart ratio $\left(\mathrm{bpm}^{\mathrm{a}}\right)$ & $72(12)$ & $74(12)$ \\
\hline Total cholesterol (mg/dL) & $198(36)$ & $202(40)$ \\
\hline $\mathrm{HDL}^{\mathrm{b}}$ cholesterol (mg/dL) & $51(13)$ & $52(12)$ \\
\hline \multicolumn{3}{|l|}{ BMI classification $\left(\mathrm{kg} / \mathrm{m}^{2}\right), \mathrm{n}(\%)$} \\
\hline $27.5-29.9$ & $75(23.6)$ & $82(24.7)$ \\
\hline $30-40$ & $243(76.4)$ & $250(75.3)$ \\
\hline \multicolumn{3}{|l|}{ Chronic diseases, $n(\%)$} \\
\hline Hypertension & $88(27.7)$ & $116(35.0)$ \\
\hline Dyslipidemia & $73(23.4)$ & $87(26.5)$ \\
\hline Diabetes mellitus & $5(1.7)$ & $4(1.3)$ \\
\hline \multicolumn{3}{|l|}{ Medication use, $n(\%)$} \\
\hline Antihypertensive drugs & $50(15.7)$ & $69(20.8)$ \\
\hline Lipid lowering drugs & $50(15.7)$ & $56(16.9)$ \\
\hline
\end{tabular}




\begin{tabular}{lll}
\hline Characteristics & Intervention $(\mathrm{n}=318)$ & Control $(\mathrm{n}=332)$ \\
\hline Hypothyroid drugs & $31(9.8)$ & $37(11.1)$ \\
\hline
\end{tabular}

abm: beats per minute.

${ }^{\mathrm{b}} \mathrm{HDL}$ : high-density lipoprotein.

\section{Adherence to Self-monitoring on the Smartphone App}

Adherence to self-monitoring on the smartphone app was calculated from the app output data by an independent researcher. The median app use was 64.5 days out of the 90 days of the intervention $(71.67 \%)$. Of the 318 participants assigned to the IG, $150(47.2 \%)$ adhered sufficiently by recording data in the app between 61 and 90 days. In total, 3 participants did not register any food, and there were 36 data files from which no information was available for technical reasons (Multimedia Appendix 2). Multimedia Appendix 3 displays the median days of app use out of the 90 days in percentage to show adherence to self-monitoring on the app, grouped by sex, marital status, and age.

\section{Changes in Weight and Anthropometric Variables During the Study Period}

Table 2 shows the decrease in body weight at 3 and 12 months in both groups. Comparing groups, the IG achieved a net weight loss difference of $0.76(95 \% \mathrm{CI}-1.33$ to -0.19$) \mathrm{kg}$ at 3 months and $0.26(95 \% \mathrm{CI}-1.21$ to $0.70 ; P=.02) \mathrm{kg}$ at 12 months, more than the CG. The overall weight reduction of the IG was $2.05 \%$ at 3 months and $1.58 \%$ at 12 months, while the CG showed $1.1 \%$ and $1.26 \%$ reductions in body weight at 3 and 12 months, respectively. Only $18.2 \%(52 / 285)$ of the IG participants achieved a clinically significant weight loss of $\geq 5 \%$ at the 3 months visit and $19.4 \%(42 / 216)$ of them achieved that percentage at 12 months. In the CG, 12.9\% (35/271) achieved a weight loss of $5 \%$ at 3 months and $18.5 \%(42 / 227)$ reached that loss at the 12-month visit. Regarding adherence to self-monitoring on the app, both in number of days used and median percentage of days, a positive correlation was found at 3 months with weight loss $(r=0.239 ; P<.001)$ and BMI $(r=0.203$; $P<.001)$ but not at 12 months or with weight $(r=0.015 ; P=.83)$ and BMI $(r=0.021 ; P=.77)$.

In addition, the IG showed changes in waist circumference $(-0.76,95 \% \mathrm{CI}-1.47$ to $-0.05 \mathrm{~cm})$ and hip circumference $(-1.02,95 \% \mathrm{CI}-1.68$ to $-0.34 \mathrm{~cm})$ compared with the $\mathrm{CG}$ at 3 months. Similar results were found at 12 months, with net decreases in waist circumference $(-0.48,95 \% \mathrm{CI}-1.62$ to 0.66 $\mathrm{cm})$ and hip circumference $(-0.69,95 \% \mathrm{CI}-1.62$ to $0.25 \mathrm{~cm}$; $P=.04$ and $P=.03$, respectively) between groups. Regarding body composition parameters, BMI decreased at 3 months $(-0.30,95 \% \mathrm{CI}-0.52$ to -0.09 points) and slightly changed at 12 months $(-0.06,95 \% \mathrm{CI}-0.41$ to 0.28 points; $P=.01)$, comparing the study groups. Similar results were found for waist-height ratio at 3 months $(-0.48,95 \% \mathrm{CI}-0.92$ to -0.04$)$ and 12 months $(-0.25,95 \% \mathrm{CI}-0.94$ to $0.44 ; P=.03)$ and body adiposity index at 3 months $(-0.50,95 \% \mathrm{CI}-0.81$ to -0.18$)$ and 12 -month follow-up $(-0.33,95 \% \mathrm{CI}-0.77$ to $0.11 ; P=.03)$ between groups. Although the IG tended to show decreases in the rest of the indexes analyzed (waist-hip ratio, body shape index, and body roundness index) at both follow-up visits, no significant differences were observed between groups.

Figure 3 shows the evolution of the main anthropometric parameters analyzed over time, with a decrease at 3 months in both groups, especially in the IG. However, the downward trend was not maintained in the IG at 12 months, while the CG continued to decrease. 
Table 2. Effect of the mobile health intervention on body weight and other anthropometric parameters.

\begin{tabular}{|c|c|c|c|c|c|c|c|}
\hline \multirow[t]{2}{*}{ Parameters } & \multicolumn{2}{|c|}{ Intervention group $(n=318)$} & \multicolumn{2}{|c|}{ Control group $(n=332)$} & \multicolumn{2}{|l|}{ Net difference } & \multirow[b]{2}{*}{$P$ value ${ }^{\mathrm{b}}$} \\
\hline & Values & $P$ value & Values & $P$ value & Values & $P$ value $^{\mathrm{a}}$ & \\
\hline \multicolumn{8}{|l|}{ Weight (kg) } \\
\hline Baseline, mean (SD) & $91.4(14.8)$ & $\mathrm{N} / \mathrm{A}^{\mathrm{c}}$ & $91.1(14.8)$ & $\mathrm{N} / \mathrm{A}$ & N/A & $\mathrm{N} / \mathrm{A}$ & $\mathrm{N} / \mathrm{A}$ \\
\hline $\begin{array}{l}\text { 3-month change, mean difference } \\
(95 \% \mathrm{CI})\end{array}$ & $\begin{array}{l}-1.79(-2.20 \text { to } \\
-1.37)\end{array}$ & $<.001$ & $\begin{array}{l}-1.03(-1.41 \text { to } \\
-0.64)\end{array}$ & $<.001$ & $\begin{array}{l}-0.76(-1.33 \text { to } \\
-0.19)\end{array}$ & $\mathrm{N} / \mathrm{A}$ & $\mathrm{N} / \mathrm{A}$ \\
\hline $\begin{array}{l}\text { 12-month change, mean differ- } \\
\text { ence }(95 \% \mathrm{CI})\end{array}$ & $\begin{array}{l}-1.46(-2.15 \text { to } \\
-0.77)\end{array}$ & $<.001$ & $\begin{array}{l}-1.20(-1.87 \text { to } \\
-0.54)\end{array}$ & $<.001$ & $\begin{array}{l}-0.26(-1.21 \text { to } \\
0.70)\end{array}$ & .03 & .02 \\
\hline \multicolumn{8}{|l|}{ Waist circumference $(\mathrm{cm})$} \\
\hline Baseline, mean (SD) & $107.4(12.9)$ & N/A & $107.4(10.7)$ & N/A & N/A & N/A & N/A \\
\hline $\begin{array}{l}\text { 3-month change, mean difference } \\
(95 \% \mathrm{CI})\end{array}$ & $\begin{array}{l}-2.18(-2.71 \text { to } \\
-1.65)\end{array}$ & $<.001$ & $\begin{array}{l}-1.42(-1.90 \text { to } \\
-0.94)\end{array}$ & $<.001$ & $\begin{array}{l}-0.76(-1.47 \text { to } \\
-0.05)\end{array}$ & $\mathrm{N} / \mathrm{A}$ & N/A \\
\hline $\begin{array}{l}\text { 12-month change, mean differ- } \\
\text { ence }(95 \% \mathrm{CI})\end{array}$ & $\begin{array}{l}-2.28(-3.14 \text { to } \\
-1.43)\end{array}$ & $<.001$ & $\begin{array}{l}-1.80(-2.57 \text { to } \\
-1.04)\end{array}$ & $<.001$ & $\begin{array}{l}-0.48(-1.62 \text { to } \\
0.66)\end{array}$ & .04 & .04 \\
\hline \multicolumn{8}{|l|}{ Hip circumference (cm) } \\
\hline Baseline, mean (SD) & $116.4(11.4)$ & N/A & $115.5(9.3)$ & N/A & N/A & N/A & N/A \\
\hline $\begin{array}{l}\text { 3-month change, mean difference } \\
(95 \% \mathrm{CI})\end{array}$ & $\begin{array}{l}-1.96(-2.42 \text { to } \\
-1.50)\end{array}$ & $<.001$ & $\begin{array}{l}-0.94(-1.42 \text { to } \\
-0.47)\end{array}$ & $<.001$ & $\begin{array}{l}-1.02(-1.67 \text { to } \\
-0.36)\end{array}$ & $\mathrm{N} / \mathrm{A}$ & $\mathrm{N} / \mathrm{A}$ \\
\hline $\begin{array}{l}\text { 12-month change, mean differ- } \\
\text { ence }(95 \% \mathrm{CI})\end{array}$ & $\begin{array}{l}-1.81(-2.47 \text { to } \\
-1.16)\end{array}$ & $<.001$ & $\begin{array}{l}-1.13(-1.79 \text { to } \\
-0.46)\end{array}$ & .001 & $\begin{array}{l}-0.69(-1.62 \text { to } \\
0.25)\end{array}$ & .03 & .03 \\
\hline \multicolumn{8}{|l|}{ BMI $\left(\mathrm{kg} / \mathbf{m}^{2}\right)$} \\
\hline Baseline, mean (SD) & $33.1(3.4)$ & $\mathrm{N} / \mathrm{A}$ & $32.9(3.6)$ & N/A & N/A & N/A & N/A \\
\hline $\begin{array}{l}\text { 3-month change, mean difference } \\
(95 \% \mathrm{CI})\end{array}$ & $\begin{array}{l}-0.69(-0.85 \text { to } \\
-0.53)\end{array}$ & $<.001$ & $\begin{array}{l}-0.38(-0.52 \text { to } \\
-0.24)\end{array}$ & $<.001$ & $\begin{array}{l}-0.30(-0.52 \text { to } \\
-0.09)\end{array}$ & $\mathrm{N} / \mathrm{A}$ & $\mathrm{N} / \mathrm{A}$ \\
\hline $\begin{array}{l}\text { 12-month change, mean differ- } \\
\text { ence }(95 \% \mathrm{CI})\end{array}$ & $\begin{array}{l}-0.49(-0.74 \text { to } \\
-0.24)\end{array}$ & $<.001$ & $\begin{array}{l}-0.43(-0.66 \text { to } \\
-0.19)\end{array}$ & $<.001$ & $\begin{array}{l}-0.06(-0.41 \text { to } \\
0.28)\end{array}$ & .02 & .01 \\
\hline \multicolumn{8}{|l|}{ Waist-height ratio } \\
\hline Baseline, mean (SD) & $64.82(6.9)$ & N/A & $64.76(5.7)$ & N/A & N/A & N/A & N/A \\
\hline $\begin{array}{l}\text { 3-month change, mean difference } \\
(95 \% \mathrm{CI})\end{array}$ & $\begin{array}{l}-1.35(-1.68 \text { to } \\
-1.02)\end{array}$ & $<.001$ & $\begin{array}{l}-0.87(-1.16 \text { to } \\
-0.58)\end{array}$ & $<.001$ & $\begin{array}{l}-0.48(-0.92 \text { to } \\
-0.04)\end{array}$ & N/A & N/A \\
\hline $\begin{array}{l}\text { 12-month change, mean differ- } \\
\text { ence }(95 \% \mathrm{CI})\end{array}$ & $\begin{array}{l}-1.34(-1.86 \text { to } \\
-0.83)\end{array}$ & $<.001$ & $\begin{array}{l}-1.09(-1.56 \text { to } \\
-0.63)\end{array}$ & $<.001$ & $\begin{array}{l}-0.25(-0.94 \text { to } \\
0.44)\end{array}$ & .04 & .03 \\
\hline \multicolumn{8}{|l|}{ Body adiposity index } \\
\hline Baseline, mean (SD) & $36.76(6.6)$ & N/A & $36.31(5.6)$ & N/A & N/A & N/A & N/A \\
\hline $\begin{array}{l}\text { 3-month change, mean difference } \\
(95 \% \mathrm{CI})\end{array}$ & $\begin{array}{l}-0.94(-1.16 \text { to } \\
-0.72)\end{array}$ & $<.001$ & $\begin{array}{l}-0.44(-0.66 \text { to } \\
-0.22)\end{array}$ & $<.001$ & $\begin{array}{l}-0.50(-0.81 \text { to } \\
-0.18)\end{array}$ & $\mathrm{N} / \mathrm{A}$ & $\mathrm{N} / \mathrm{A}$ \\
\hline $\begin{array}{l}\text { 12-month change, mean differ- } \\
\text { ence }(95 \% \mathrm{CI})\end{array}$ & $\begin{array}{l}-0.85(-1.16 \text { to } \\
-0.54)\end{array}$ & $<.001$ & $\begin{array}{l}-0.52(-0.83 \text { to } \\
-0.20)\end{array}$ & .001 & $\begin{array}{l}-0.33(-0.77 \text { to } \\
0.11)\end{array}$ & .03 & .03 \\
\hline \multicolumn{8}{|l|}{ Waist-hip ratio } \\
\hline Baseline, mean (SD) & $0.9(0.1)$ & N/A & $0.9(0.1)$ & N/A & N/A & N/A & N/A \\
\hline $\begin{array}{l}\text { 3-month change, mean difference } \\
(95 \% \mathrm{CI})\end{array}$ & $\begin{array}{l}0.00(-0.01 \text { to } \\
0.00)\end{array}$ & .07 & $\begin{array}{l}0.00(-0.01 \text { to } \\
0.00)\end{array}$ & .02 & $\begin{array}{l}0.00(-0.01 \text { to } \\
0.01)\end{array}$ & $\mathrm{N} / \mathrm{A}$ & $\mathrm{N} / \mathrm{A}$ \\
\hline $\begin{array}{l}\text { 12-month change, mean differ- } \\
\text { ence }(95 \% \mathrm{CI})\end{array}$ & $\begin{array}{l}-0.01(-0.01 \text { to } \\
0.00)\end{array}$ & .13 & $\begin{array}{l}-0.01(-0.01 \text { to } \\
0.00)\end{array}$ & .03 & $\begin{array}{l}0.00(-0.01 \text { to } \\
0.01)\end{array}$ & .51 & .46 \\
\hline \multicolumn{8}{|l|}{ Body shape index ${ }^{d}$} \\
\hline Baseline, mean (SD) & $8.1(0.6)$ & $\mathrm{N} / \mathrm{A}$ & $8.1(0.5)$ & $\mathrm{N} / \mathrm{A}$ & $\mathrm{N} / \mathrm{A}$ & N/A & $\mathrm{N} / \mathrm{A}$ \\
\hline $\begin{array}{l}\text { 3-month change, mean difference } \\
(95 \% \mathrm{CI})\end{array}$ & $\begin{array}{l}-0.06(-0.09 \text { to } \\
-0.02)\end{array}$ & .002 & $\begin{array}{l}-0.04(-0.08 \text { to } \\
-0.01)\end{array}$ & .01 & $\begin{array}{l}-0.01(-0.06 \text { to } \\
0.036)\end{array}$ & $\mathrm{N} / \mathrm{A}$ & N/A \\
\hline
\end{tabular}




\begin{tabular}{|c|c|c|c|c|c|c|c|}
\hline \multirow[t]{2}{*}{ Parameters } & \multicolumn{2}{|c|}{ Intervention group $(\mathrm{n}=318)$} & \multicolumn{2}{|c|}{ Control group ( $\mathrm{n}=332$ ) } & \multicolumn{3}{|l|}{ Net difference } \\
\hline & Values & $P$ value & Values & $P$ value & Values & $P$ value $^{\mathrm{a}}$ & $P$ value ${ }^{\mathrm{b}}$ \\
\hline $\begin{array}{l}\text { 12-month change, mean differ- } \\
\text { ence }(95 \% \mathrm{CI})\end{array}$ & $\begin{array}{l}-0.09(-0.14 \text { to } \\
-0.04)\end{array}$ & $<.001$ & $\begin{array}{l}-0.06(-0.11 \text { to } \\
-0.01)\end{array}$ & .01 & $\begin{array}{l}-0.03(-0.09 \text { to } \\
0.043)\end{array}$ & .52 & .56 \\
\hline \multicolumn{8}{|l|}{ Body roundness index } \\
\hline Baseline, mean (SD) & $6.7(1.9)$ & N/A & $6.6(1.4)$ & N/A & N/A & N/A & N/A \\
\hline $\begin{array}{l}\text { 3-month change, mean difference } \\
(95 \% \mathrm{CI})\end{array}$ & $\begin{array}{l}-0.32(-0.40 \text { to } \\
-0.24)\end{array}$ & $<.001$ & $\begin{array}{l}-0.21(-0.28 \text { to } \\
-0.14)\end{array}$ & $<.001$ & $\begin{array}{l}-0.11(-0.21 \text { to } \\
0.00)\end{array}$ & N/A & N/A \\
\hline $\begin{array}{l}\text { 12-month change, mean differ- } \\
\text { ence }(95 \% \mathrm{CI})\end{array}$ & $\begin{array}{l}-0.31(-0.43 \text { to } \\
-0.18)\end{array}$ & $<.001$ & $\begin{array}{l}-0.26(-0.37 \text { to } \\
-0.14)\end{array}$ & $<.001$ & $\begin{array}{l}-0.05(-0.22 \text { to } \\
0.12)\end{array}$ & .07 & .05 \\
\hline
\end{tabular}

${ }^{\mathrm{a}} P$ value by analysis of variance.

${ }^{\mathrm{b}} P$ value by analysis of variance adjusted by age and sex.

${ }^{\mathrm{c}} \mathrm{N} / \mathrm{A}$ : not applicable.

${ }^{\mathrm{d}}$ Body Round Shape results are displayed multiplied by 100 for easier reading. 
Figure 3. Evolution of weight, BMI, and other anthropometrics parameters from baseline to 3 and 12 months comparing the intervention and control group. $P$ value between groups was adjusted by age and sex: weight, $P=.02$; waist circumference, $P=.04$; hip circumference, $P=.03$; BMI, $P=.01$; waist-height ratio, $P=.03$; and body adiposity index, $P=.03$.
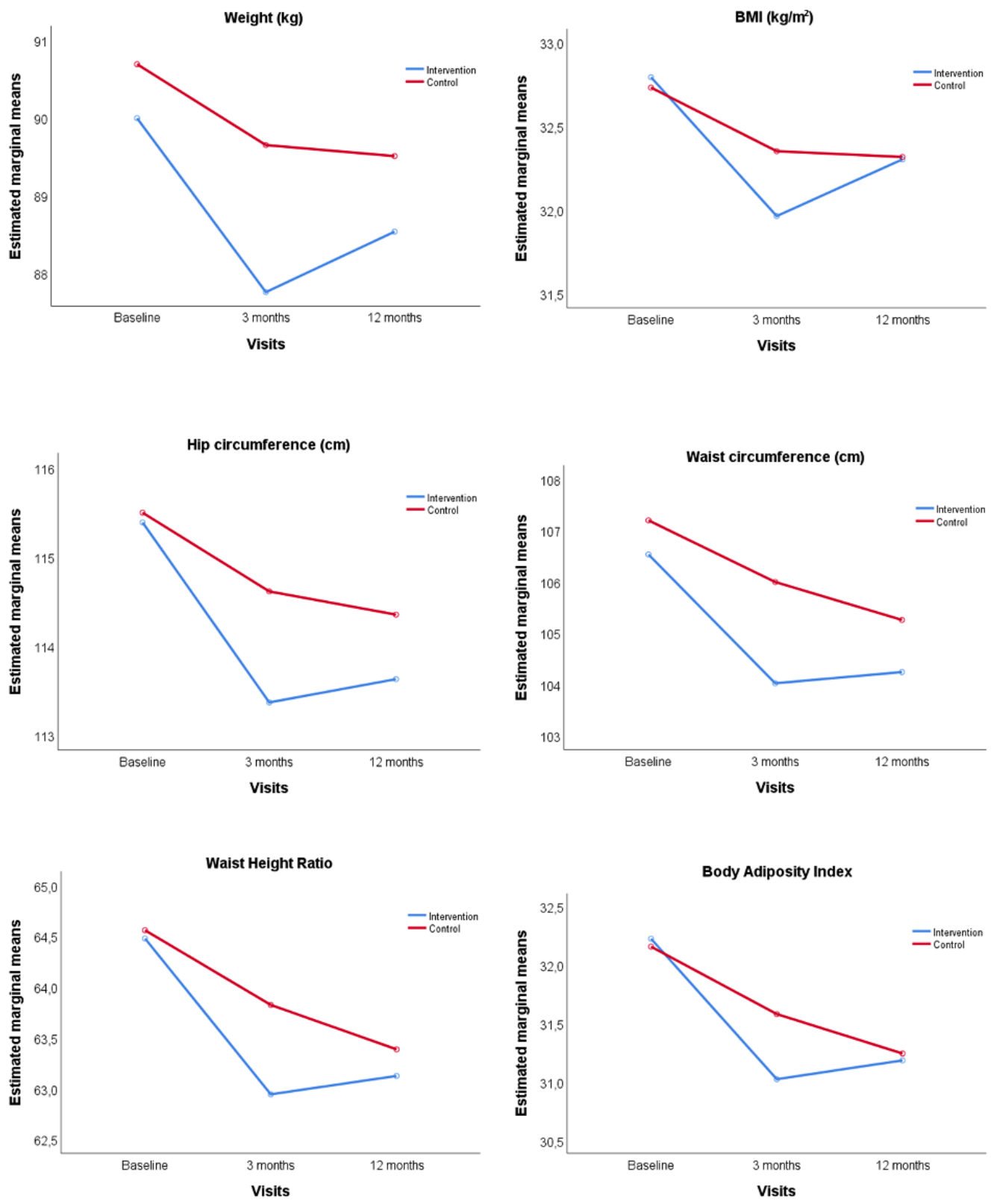

\section{Changes in Diet and Physical Activity}

In terms of diet, daily caloric intake was lower in both groups (IG: $-295,95 \%$ CI -391.63 to $-198.93 \mathrm{kcal} /$ day; CG: -222 , $95 \% \mathrm{CI}-310.62$ to $-135.14 \mathrm{kcal} / \mathrm{day}$ ) at 12 months, with no significant differences between groups (Table 3). The Mediterranean diet adherence increased in both groups at 3 and 12 months, but the differences were not statistically significant. The IG experienced a trend toward increased adherence to the Mediterranean diet at 3 months, but decreased at 12 months, while adherence was maintained in the CG.

Physical activity time in all intensities (light, moderate, and vigorous) assessed by the IPAQ-SF increased in both groups at

3 and 12 months, whereas the time of sedentarism decreased. Although the IG tended to show greater increases in light activity, vigorous activity, and total activity time, only light physical activity (LPA) time showed a net increase of $81.2(95 \%$ CI 31.93-130.58) minutes per week at 3 months and $32.6(95 \%$ $\mathrm{CI}-30.31$ to 95.04$)$ minutes per week at 12 months $(P=.02)$ compared with the CG. Regarding the smart band, Multimedia Appendix 4 shows the correlation between the IPAQ-SF data (METs per week and min/week for each activity level) at 3 months in the IG and the information collected from the smart band after 3 months of the intervention (daily average of steps and activity minutes), with a low correlation between variables, which was higher in women than in men. 
Table 3. Effect of the mobile health intervention on diet and physical activity variables.

\begin{tabular}{|c|c|c|c|c|c|c|}
\hline \multirow[t]{2}{*}{ Variables } & \multicolumn{2}{|c|}{ Intervention group $(\mathrm{n}=318)$} & \multicolumn{2}{|l|}{ Control group (n=332) } & \multicolumn{2}{|l|}{ Net difference } \\
\hline & Value & $P$ value & Value & $P$ value & Value & $P$ value \\
\hline \multicolumn{7}{|l|}{ Energy intake (kcal) } \\
\hline Baseline, mean (SD) & $2394.1(676.4)$ & $N / A^{b}$ & $2359.9(681.1)$ & N/A & N/A & N/A \\
\hline $\begin{array}{l}\text { 3-month change, mean difference } \\
(95 \% \mathrm{CI})\end{array}$ & $\begin{array}{l}-204.18(-285.46 \text { to } \\
-122.89)\end{array}$ & $<.001$ & $\begin{array}{l}-189.84(-268.94 \text { to } \\
-110.73)\end{array}$ & $<.001$ & $\begin{array}{l}-14.34(-127.48 \text { to } \\
98.80)\end{array}$ & N/A \\
\hline $\begin{array}{l}\text { 12-month change, mean difference } \\
(95 \% \mathrm{CI})\end{array}$ & $\begin{array}{l}-295.28(-391.63 \text { to } \\
-198.93)\end{array}$ & $<.001$ & $\begin{array}{l}-222.88(-310.62 \text { to } \\
-135.14)\end{array}$ & $<.001$ & $\begin{array}{l}-72.40(-202.13 \text { to } \\
57.33)\end{array}$ & .59 \\
\hline \multicolumn{7}{|l|}{ Score for adherence to $\mathrm{MD}^{\mathrm{c}}$ (points) } \\
\hline Baseline, mean (SD) & $7.1(1.9)$ & N/A & $7.1(1.9)$ & N/A & N/A & N/A \\
\hline $\begin{array}{l}\text { 3-month change, mean difference } \\
(95 \% \mathrm{CI})\end{array}$ & $0.56(0.34$ to 0.78$)$ & $<.001$ & $0.41(0.19$ to 0.60$)$ & $<.001$ & $0.15(-0.15$ to 0.45$)$ & N/A \\
\hline $\begin{array}{l}\text { 12-month change, mean difference } \\
(95 \% \mathrm{CI})\end{array}$ & $0.37(0.12$ to 0.63$)$ & .005 & $0.56(0.29$ to 0.82$)$ & $<.001$ & $-0.19(-0.56$ to 0.17$)$ & .06 \\
\hline \multicolumn{7}{|l|}{ Score adherence to $\mathrm{MD}$ ( $\geq 9$ points) } \\
\hline Baseline, n (\%) & $81(25.3)$ & N/A & $84(25.4)$ & N/A & N/A & N/A \\
\hline $\begin{array}{l}\text { 3-month change, percentage differ- } \\
\text { ence }(95 \% \mathrm{CI})\end{array}$ & 8.04 (2.07 to 14.02$)$ & .009 & $5.90(0.22$ to 11.59$)$ & .04 & $2.14(-6.11$ to 10.39$)$ & N/A \\
\hline $\begin{array}{l}\text { 12-month change, percentage differ- } \\
\text { ence }(95 \% \mathrm{CI})\end{array}$ & $6.45(-0.89$ to 13.80$)$ & .09 & $11.66(4.74$ to 18.58$)$ & .001 & $-5.21(-15.26$ to 4.85$)$ & .19 \\
\hline \multicolumn{7}{|l|}{ Light activity (min/week) } \\
\hline Baseline, mean (SD) & $259.9(283.4)$ & N/A & $259.8(287.9)$ & N/A & N/A & N/A \\
\hline $\begin{array}{l}\text { 3-month change, mean difference } \\
(95 \% \mathrm{CI})\end{array}$ & $\begin{array}{l}102.85 \text { (70.46 to } \\
135.26)\end{array}$ & $<.001$ & $21.60(-15.96$ to 59.16$)$ & .26 & 81.26 (31.93 to 130.58$)$ & N/A \\
\hline $\begin{array}{l}\text { 12-month change, mean difference } \\
(95 \% \mathrm{CI})\end{array}$ & 91.21 (58.76 to 125.65$)$ & $<.001$ & 58.85 (6.24 to 111.46$)$ & .03 & $32.36(-30.31$ to 95.04$)$ & .02 \\
\hline \multicolumn{7}{|l|}{ Moderate activity (min/week) } \\
\hline Baseline, mean (SD) & $53.0(154.2)$ & N/A & $41.3(133.6)$ & N/A & N/A & N/A \\
\hline $\begin{array}{l}\text { 3-month change, mean difference } \\
(95 \% \mathrm{CI})\end{array}$ & $19.10(-7.80$ to 46.01$)$ & .16 & 44.32 (22.06 to 66.57$)$ & $<.001$ & $-25.21(-60.27$ to 9.85$)$ & N/A \\
\hline $\begin{array}{l}\text { 12-month change, mean difference } \\
(95 \% \mathrm{CI})\end{array}$ & 2.04 ( -28.58 to 32.65$)$ & .90 & $38.90(13.54$ to 64.26$)$ & .003 & $-36.86(-76.39$ to 2.66$)$ & .06 \\
\hline \multicolumn{7}{|l|}{ Vigorous activity (min/week) } \\
\hline Baseline, mean (SD) & $39.2(228.0)$ & N/A & $30.7(143.2)$ & N/A & N/A & N/A \\
\hline $\begin{array}{l}\text { 3-month change, mean difference } \\
(95 \% \mathrm{CI})\end{array}$ & $20.80(-1.26$ to 42.85$)$ & .06 & $13.73(-15.81$ to 42.26$)$ & .36 & $7.07(-29.44$ to 43.58$)$ & N/A \\
\hline $\begin{array}{l}\text { 12-month change, mean difference } \\
(95 \% \mathrm{CI})\end{array}$ & $25.29(2.98$ to 47.59$)$ & .03 & $17.37(-4.92$ to 39.66$)$ & .13 & $7.92(-23.54$ to 39.37$)$ & .82 \\
\hline \multicolumn{7}{|l|}{ Moderate to vigorous activity (min/week) } \\
\hline Baseline, mean (SD) & $92.2(293.5)$ & N/A & $71.9(195.4)$ & N/A & N/A & N/A \\
\hline $\begin{array}{l}\text { 3-month change, mean difference } \\
(95 \% \mathrm{CI})\end{array}$ & $39.89(5.07$ to 74.73$)$ & .03 & 58.04 (16.83 to 99.26$)$ & .006 & $\begin{array}{l}-18.15(-71.77 \text { to } \\
35.48)\end{array}$ & N/A \\
\hline $\begin{array}{l}\text { 12-month change, mean difference } \\
(95 \% \mathrm{CI})\end{array}$ & $27.33(-15.38$ to 70.03$)$ & .21 & 56.27 (18.59 to 93.96$)$ & .004 & $\begin{array}{l}-28.95(-85.63 \text { to } \\
27.73)\end{array}$ & .33 \\
\hline \multicolumn{7}{|l|}{ Total activity time (min/week) } \\
\hline Baseline, mean (SD) & $351.1(415.8)$ & N/A & $331.7(345.2)$ & N/A & N/A & N/A \\
\hline $\begin{array}{l}\text { 3-month change, mean difference } \\
(95 \% \mathrm{CI})\end{array}$ & $\begin{array}{l}142.75(94.90 \text { to } \\
190.61)\end{array}$ & $<.001$ & 79.65 (24.27 to 135.02$)$ & .005 & $63.11(-9.68$ to 135.90$)$ & N/A \\
\hline
\end{tabular}




\begin{tabular}{|c|c|c|c|c|c|c|}
\hline \multirow[t]{2}{*}{ Variables } & \multicolumn{2}{|c|}{ Intervention group $(\mathrm{n}=318)$} & \multicolumn{2}{|c|}{ Control group $(\mathrm{n}=332)$} & \multicolumn{2}{|l|}{ Net difference } \\
\hline & Value & $P$ value & Value & $P$ value & Value & $P$ value ${ }^{\mathrm{a}}$ \\
\hline $\begin{array}{l}\text { 12-month change, mean difference } \\
(95 \% \mathrm{CI})\end{array}$ & $\begin{array}{l}118.53(60.59 \text { to } \\
176.48)\end{array}$ & $<.001$ & $\begin{array}{l}115.12(45.01 \text { to } \\
185.23)\end{array}$ & .001 & $3.41(-87.63$ to 94.46$)$ & .57 \\
\hline \multicolumn{7}{|l|}{ Total sitting time (min/week) } \\
\hline Baseline, mean (SD) & $2903.6(1397.3)$ & N/A & $2805.9(1347.6)$ & N/A & N/A & N/A \\
\hline $\begin{array}{l}\text { 3-month change, mean difference } \\
(95 \% \mathrm{CI})\end{array}$ & $\begin{array}{l}-174.98(-294.58 \text { to } \\
-55.40)\end{array}$ & .004 & $\begin{array}{l}-42.74(-160.90 \text { to } \\
75.42)\end{array}$ & .48 & $\begin{array}{l}-132.24(-300.17 \text { to } \\
35.70)\end{array}$ & N/A \\
\hline $\begin{array}{l}\text { 12-month change, mean difference } \\
(95 \% \mathrm{CI})\end{array}$ & $\begin{array}{l}-259.84(-389.54 \text { to } \\
-130.16)\end{array}$ & $<.001$ & $\begin{array}{l}-94.28(-239.15 \text { to } \\
50.60)\end{array}$ & .20 & $\begin{array}{l}-165.57(-359.74 \text { to } \\
28.60)\end{array}$ & .09 \\
\hline
\end{tabular}

${ }^{\mathrm{a}} P$ value by analysis of variance.

${ }^{\mathrm{b}} \mathrm{N} / \mathrm{A}$ : not applicable.

${ }^{\mathrm{c}} \mathrm{MD}$ : Mediterranean diet.

\section{Analyses of the Effect Stratified by Baseline Characteristics}

Only women experienced decreases in weight, waist, and other anthropometric parameters analyzed, except for waist-hip ratio, body shape index, and body roundness index, with a net weight loss of $0.50(95 \% \mathrm{CI}-1.53$ to $0.54 ; P=.002) \mathrm{kg}$ at 12 months. With regard to age, those aged $<50$ years showed a decrease in hip circumference, while people aged $>50$ years showed a reduction in weight and BMI. Finally, analysis by marital status showed that only married people showed decreases in weight $(-0.90,95 \% \mathrm{CI}-2.0$ to $0.2 \mathrm{~kg} ; P=.02), \mathrm{BMI}(-0.3,95 \% \mathrm{CI}-0.7$ to 0.1 points; $P=.01$ ), and other anthropometric parameters at 12 months. These analyses are presented in Multimedia Appendix 5.

\section{Discussion}

\section{Principal Findings}

\section{Overview}

The Evident 3 study evaluated the intervention effect and its maintenance over time at 3 and 12 months after the baseline visit. The main findings of the use of a smartphone app in combination with an activity tracker wristband for 3 months and brief counseling showed a greater weight loss compared with the CG, but once these devices were collected, the trend was not maintained at 12 months. Although both groups had reduced weight, BMI, and other anthropometric variables, the IG showed a greater trend to reduce weight, BMI, waist and hip circumference, waist-height ratio, and body adiposity index at the 3-month follow-up and did not maintain a downward trend at the 12-month visit. Regarding diet, both groups decreased their caloric intake (kcal) and improved their Mediterranean diet adherence, but no differences between groups were found. A similar result was observed in physical activity, where physical activity time increased in both groups, but the IG showed an increase in weekly LPA time at 12 months. Analyses stratified by baseline characteristics showed patterns toward greater changes in body composition variables in women, people aged $>50$ years, and married people.

\section{Weight}

Findings from meta-analyses have shown that mHealth weight loss interventions were effective in comparison with minimal intervention or control in the short term but with inconclusive long-term results $[15,16]$. The Evident 3 study provides insights into the long-term effects of weight loss, BMI, and other anthropometric variables at 3 months, but this trend was not maintained in the period when they no longer had access to the devices up to the 12-month visit. In addition, overall weight reduction in the IG was $2.05 \%$ at 3 months, so clinically relevant weight loss was not achieved (>5\%).

Despite the heterogeneity found in these types of interventions, some systematic reviews [23,49] suggest that the combination of mHealth tools could be useful for changing lifestyles to healthier ones, but its effect on weight loss remains unclear. Along these lines, the Innovative Approaches to Diet, Exercise and Activity study, which provided a wearable technology combined with a website to the enhanced IG, found no significant difference in weight or physical activity between groups [29] across the 24-month intervention in young adults. Moreover, another study that evaluated the effect of a web-based weight loss program with and without an activity tracking device found that its addition to the intervention did not produce higher changes in weight loss at the 12-month follow-up [50] than those in the CG. In contrast, the Quant study, whose intervention included 3 feedback devices (Bioelectrical Impedance Analysis scale, blood pressure, and step counter) found a positive effect on fat loss at the 12-month follow-up [51]. These results are consistent with those found in our study, where there were differences between groups in weight, body composition variables, and physical activity but without reaching clinically relevant results.

Notwithstanding the effectiveness of self-monitoring behaviors in weight management [52], the challenge lies in finding a way to keep the users using the app, because the frequency of logging into the app is highly related to weight loss success in web-based interventions [53] and mHealth apps [52], as the user adopts new behaviors over time that is supported by the tools. In this regard, the rate of users who adhered sufficiently to the study app $(150 / 318,47.2 \%)$ may be insufficient to show better results in the main outcomes at 12 months. It should also be noted that 
between the period in which mHealth tools were collected at the 3-month follow-up and the 12-month visit, there was no reinforcement or any contact with the participants by the researchers. Therefore, despite not obtaining clinically relevant weight loss, the results suggest that the intervention should be modified (longer intervention period, improved adherence strategies, some professional support, etc), as the trend of weight reduction was not maintained over time when tools were removed. Moreover, the CG also reported weight loss but lower than that of the IG, which is commonly reported in weight loss interventions [25], especially if the CG received usual care [54].

\section{Physical Activity and Diet}

The study intervention, which included an activity tracker wristband, was shown to increase weekly LPA time measured by the IPAQ-SF. Increasing LPA may improve important health outcomes, such as markers of lipid and glucose metabolism and mortality in the general population [55]. Although the general physical activity recommendations are based on promoting moderate to vigorous physical activity, increasing LPA in the sedentary population may be a good starting point for decreasing inactivity in people with overweight and obesity [56]. Previous studies have reported beneficial changes in physical activity variables, observing a small increase in moderate to vigorous physical activity in women [57] and people with overweight and obesity [22] or in steps per day [20] in people with chronic diseases. Specifically, a recent study reported increased resistance training and reduced energy intake at 6 months using a multicomponent mHealth intervention [25], showing the potential of these tools in physical activity promotion by allowing a more tailored intervention and greater feedback.

Furthermore, energy intake was reduced, and adherence to the Mediterranean diet increased in both groups. However, the app intervention did not achieve better results than the CG. Potential explanations for this include that the brief diet counseling using the plate method was explained at the end of the baseline visit, which could lead to an improvement in the entire sample. Moreover, Solbrig et al [58] suggested that there is a mismatch between people's need for help and what weight management apps provide, as people dislike counting calories, the basis of most self-management apps, and need more tailored support and motivational elements. Along these lines, a recent study found that a digital app that provides personalized nutritional recommendations appeared to be successful in reducing weight in users with obesity [59]. Future research will focus on the inclusion of new adaptive features in health apps to achieve greater results in health outcomes and higher rates of intervention adherence.

\section{Analyses of the Effect Stratified by Baseline Characteristics}

These analyses showed that the intervention was more effective in specific groups than in the general IG. Women showed greater weight loss, BMI changes, and other anthropometric variables, whereas men did not show differences. This could be explained by the higher rate of participation by women in this study $(445 / 650,68.5 \%)$, following the trend of weight management studies [60] and by the lower number of men included $(n=205)$, which may have resulted in an underpowered analysis to find differences in the male group. In addition, women are more likely to participate in weight loss interventions [61] and use health apps [62], so the sex factor has to be considered. Regarding age, people aged $>50$ years obtained differences in more outcomes than younger people, and they were more adherent to the self-monitoring on the app. A systematic review found that middle-aged adults are more willing to adhere to such interventions with activity trackers [63] than younger people, so it is feasible that differences are found between age groups, as in the study results. In terms of marital status, married people seem to benefit more from the intervention. However, the unequal size of the groups could explain why single people, who obtained higher median adherence days than married people, did not show positive results. The influence of sociodemographic factors on the digital intervention effect, or adherence, has to be explored in-depth, but a study among users of eHealth approaches suggested that married people, among other characteristics, generally used more mHealth apps [64], which might lead to more positive results. Although more research is needed to determine which personal factors could influence mHealth effectiveness, these analyses highlight the need to develop more tailored interventions, adapting them according to certain characteristics of the user to enhance the effect of these digital approaches.

Finally, the average dropout rate was higher than expected $(207 / 650,31.8 \%)$ but balanced between study groups (IG: $102 / 318,32.1 \%$ vs CG: $105 / 332,31.6 \%$ ). As a group, the participants who dropped out of the study were younger, with greater mean weight, BMI $>30 \mathrm{~kg} / \mathrm{m}^{2}$, and a higher proportion of smokers, in line with the dropout predictors found by a systematic review [65]. The participant attrition rate from digital interventions often exceeds $20 \%$ [66], and it is common to find large dropouts in weight management mobile phone apps [67] and multicomponent interventions [51]. Potential explanations could be participants' higher weight loss expectations [65] and experiencing difficulty in maintaining self-monitoring.

\section{Strengths and Limitations}

This study had several strengths. The study included a large sample with a multisite design with a wide range of ages and educational background, which offers robustness to the results obtained. Both the intervention and the statistical analysis were conducted by blinding researchers to the assignment groups. The 3- and 12-month visits allowed evaluation of the short-term and long-term effects of this type of technology on weight loss in the absence of additional face-to-face intervention. Moreover, the adherence rate to the self-monitoring diet on the app was acceptable (median percentage of days $71.7 \%$ ).

In addition, some limitations of this study should be noted. Although participants were instructed not to use any other mHealth tool that could interfere with the study, there are no guarantees to ensure this occurred. The data collected from the smart band did not allow for the assessment of daily use and adherence to this device. In addition, the nature of the intervention precludes blinding of the participants, although recent findings suggest that blinding is less important than often believed [68]. The exposure time to the intervention (3 months) might not be sufficient to identify more positive results in 
changing lifestyles and weight loss. The number of participants in each baseline characteristics (sex, age, and marital status) group could be insufficient to show more relevant effects in the stratified analysis. Finally, the dropout rate of $31.8 \%$ (207/650) may have biased the final sample study composition and underpowered the study with regard to detecting a significant effect in the results between groups. However, random allocation and a balanced dropout between arms show that the group characteristics differ little from the initial sample, making the comparison between groups possible [69].

\section{Conclusions}

The low-intensity intervention of the Evident 3 study showed in the IG, benefits on weight loss, some body composition variables, and time spent in LPA compared with the CG at 3 months, but once the devices were collected, the downward trend was not maintained at the 12-month follow-up. No differences in nutritional outcomes were observed between the groups. Analyses stratified by baseline characteristics revealed that the intervention was more effective in women, people aged $\geq 50$ years, and married participants. Further research is needed to determine the optimum intervention period to achieve greater results, as well as the inclusion of more tailored strategies in health apps and weight management interventions that improve intervention adherence and retention rates.

\section{Acknowledgments}

This study was funded by the Spanish Ministry of Science and Innovation, Instituto de Salud Carlos III and cofunded by the European Union (ERDF/ESF, "Investing in your future"; RD16/0007/0003, RD16/0007/0005, RD16/0007/0008, and RD16/0007/0009; and PI16/00101, PI16/00952, PI16/00765, PI16/00659, PI16/00421, PI16/00170, and FI17/00040; REDIAPP). Gerencia Regional de Salud de Castilla y Leon (GRS 1277/B/16 and GRS 1580/B/17) also collaborated with the funding of this study. They played no role in the study design, data analysis, reporting results, or the decision to submit the manuscript for publication.

The Evident 3 Investigators Group comprised contributors from the following centers.

Unidad de Investigación de Atención Primaria de Salamanca (APISAL): Luis García-Ortiz (principal investigator), José I Recio-Rodríguez, Cristina Lugones-Sánchez, Manuel A Gómez-Marcos, Emiliano Rodríguez-Sánchez, Olaya Tamayo-Morales, Rosario Alonso-Domínguez, Natalia Sánchez-Aguadero, Susana González-Sánchez, Ángela de Cabo-Laso, Carmela Rodríguez-Martín, Carmen Castaño-Sánchez, Benigna Sánchez-Salgado, Jesus González-Sánchez, María C Patino-Alonso, José A Maderuelo-Fernández, Leticia Gómez-Sánchez, and Inés Llamas-Ramos.

Centro de Salud Torreramona de Zaragoza (Health Service of Aragón): Natividad González-Viejo, José Félix Magdalena-Belio, Luis Otegui-Ilarduya, Francisco J Rubio-Galán, Cristina I Sauras-Yera, Amor Melguizo-Bejar, María J Gil-Train, Marta Iribarne-Ferrer, Olga Magdalena-González, Miguel A Lafuente-Ripollés, M Mar Martínez, and Pilar Jiménez-Marcén.

Centro de Salud Cuenca I (Health Service of Castilla-La Mancha): Fernando Salcedo-Aguilar, Fructuoso Muelas-Herraiz, María A Molina-Morate, Amparo Pérez-Parra, Fernando Madero, Ángel García-Imbroda, José M Izquierdo, and María L Monterde.

Universidad de Castilla-La Mancha (University of Castilla-La Mancha): Vicente Rodríguez-Vizcaino, Alba, Soriano-Cano, Diana Patricia Pozuelo-Carrascosa, Esther Gálvez-Adalia, Alicia del Saz-Lara, and Ana Díez-Fernandez.

Centro de Salud Sta Ponça de Palma de Mallorca (Health Service of Balear Islands): José I Ramírez-Manent, José L Ferrer-Perelló, José E Romero-Palmer, Manuel Sarmiento-Cruz, Guillermo Artigues, Jitka Mudrychova, María Albaladejo-Blanco, Margarita I Moyá-Seguí, Cristina Vidal-Ribas, Patricia Lorente-Montalvo, Isabel Torrens-Darder, María M Torrens-Darder, and Lucía Pascual Calleja.

Centro de Salud San Pablo de Valladolid (Health Service of Castilla y León): María J Álvarez-Miguel, María D de Arriba-Gómez, María A Rodríguez-Fernández, Isabel Arranz-Hernando, Silvia Ramos-de la Torre, Amparo Arqueaga-Luengo, María E Moreno-Moreno, Agustina Marcos-García, Nora Manrique-Vinagre, Nieves Palomo-Blázquez, José L Montalvillo-Montalvillo, María E Fernández-Rodríguez, Alejandro González-Moro, Marta, Santiago-Pastor, María I Pérez-Concejo, and Aurora Rubio-Fernández.

Centro de Salud Casa del Barco de Valladolid (Health Service of Castilla y León): Amparo Gómez-Arranz, Carmen Fernández-Alonso, Daniel Rodríguez-Dominguez, Irene Repiso-Gento, Aventina de la Cal-de la Fuente, Rosa, Aragón-García, Miguel A Díez-Garcia, Elisa Ibañes-Jalón, Ines Castrillo-Sanz, Ana M Corcho-Castaño, Esther Jiménez-López, Daniel Correa-González, Lucía Barruso-Villafaina, Isabel Peña-García, Dolores Escudero-Terrón, Pilar Mena-Martín, Rosario Fraile-Gómez, Alberto Alonso-Gómez, Pilar Urueña, Francisca Martínez-Bermejo, Concepción Hernández-San José, Manuela Nuñez-Gómez, Patricia Sanz-Capdepont, Ana I Pazos-Revuelta, Sofía Pérez-Niño, and María E Junquera-del Pozo.

The CGB Computer Company in Salamanca, Spain, contributed to the technical development of the EVIDENT 3 app. 


\section{Authors' Contributions}

LGO, MAGM, and JIRR contributed to the conception and design of the study. LGO had full access to all of the data in the study and takes responsibility for the integrity of the data and the accuracy of data analysis. CLS, LGO, and MAGM contributed to the drafting of the paper, and CLS had the primary responsibility for the final content. LGO and MAGM contributed as senior authors to the manuscript. LGO, ERS, and MAGM contributed to the analysis and interpretation of the data. CLS, MAGM, ERS, JIRR, and LGO contributed to the critical review of the paper for important intellectual content. CLS, JIRR, CAC, IRG, EGA, MASC, and JIRM were responsible for the collection and assembly of data. All authors have read and approved the final manuscript.

\section{Conflicts of Interest}

None declared.

\section{Multimedia Appendix 1}

Baseline characteristics comparison between participants who completed the study and those who dropped out. [PDF File (Adobe PDF File), 91 KB-Multimedia Appendix 1]

\section{Multimedia Appendix 2}

Adherence to the smartphone app (number of days with a record in the app).

[PDF File (Adobe PDF File), 62 KB-Multimedia Appendix 2]

\section{Multimedia Appendix 3}

Adherence to self-monitoring on the app analyzed by the median percentage out of the 90 days of the intervention grouped by sex, marital status and age.

[PDF File (Adobe PDF File), 68 KB-Multimedia Appendix 3]

\section{Multimedia Appendix 4}

Correlations between International Physical Activity Questionnaire-Short Form and the Smart band at the 3-month visit in the intervention group.

[PDF File (Adobe PDF File), 96 KB-Multimedia Appendix 4]

\section{Multimedia Appendix 5}

Analysis of the mobile health intervention effect on weight and body composition variables grouped by baseline characteristics. [PDF File (Adobe PDF File), 117 KB-Multimedia Appendix 5]

\section{Multimedia Appendix 6}

CONSORT eHEALTH Checklist (V 1.6.1).

[PDF File (Adobe PDF File), 335 KB-Multimedia Appendix 6]

\section{References}

1. $\mathrm{Xu} \mathrm{H}$, Cupples LA, Stokes A, Liu C. Association of obesity with mortality over 24 years of weight history: findings from the Framingham heart study. JAMA Netw Open 2018 Nov 02;1(7):e184587 [FREE Full text] [doi: 10.1001/jamanetworkopen.2018.4587] [Medline: $\underline{30646366]}$

2. Martinson BC, O'Connor PJ, Pronk NP. Physical inactivity and short-term all-cause mortality in adults with chronic disease. Arch Intern Med 2001 May 14;161(9):1173-1180. [doi: 10.1001/archinte.161.9.1173] [Medline: 11343440]

3. Stenholm S, Head J, Kivimäki M, Kawachi I, Aalto V, Zins M, et al. Smoking, physical inactivity and obesity as predictors of healthy and disease-free life expectancy between ages 50 and 75: a multicohort study. Int J Epidemiol 2016 Aug;45(4):1260-1270 [FREE Full text] [doi: 10.1093/ije/dyw126] [Medline: 27488415]

4. Lavie CJ, McAuley PA, Church TS, Milani RV, Blair SN. Obesity and cardiovascular diseases: implications regarding fitness, fatness, and severity in the obesity paradox. J Am Coll Cardiol 2014 Apr 15;63(14):1345-1354 [FREE Full text] [doi: 10.1016/j.jacc.2014.01.022] [Medline: 24530666]

5. Withrow D, Alter D. The economic burden of obesity worldwide: a systematic review of the direct costs of obesity. Obes Rev 2011 Feb;12(2):131-141. [doi: 10.1111/j.1467-789X.2009.00712.x] [Medline: 20122135]

6. Acosta A, Streett S, Kroh MD, Cheskin LJ, Saunders KH, Kurian M, et al. White Paper AGA: POWER - Practice guide on obesity and weight management, education, and resources. Clin Gastroenterol Hepatol 2017 May;15(5):631-649. [doi: 10.1016/j.cgh.2016.10.023] [Medline: 28242319] 
7. Baillot A, Romain A, Boisvert-Vigneault K, Audet M, Baillargeon J, Dionne I, et al. Effects of lifestyle interventions that include a physical activity component in class II and III obese individuals: a systematic review and meta-analysis. PLoS One 2015 Apr 1;10(4):e0119017 [FREE Full text] [doi: 10.1371/journal.pone.0119017] [Medline: 25830342]

8. Hassan Y, Head V, Jacob D, Bachmann M, Diu S, Ford J. Lifestyle interventions for weight loss in adults with severe obesity: a systematic review. Clin Obes 2016 Dec;6(6):395-403. [doi: 10.1111/cob.12161] [Medline: 27788558]

9. WHO Guideline: Recommendations on Digital Interventions for Health System Strengthening. Geneva: World Health Organization; 2018.

10. Agnihothri S, Cui L, Delasay M, Rajan B. The value of mHealth for managing chronic conditions. Health Care Manag Sci 2020 Jun;23(2):185-202. [doi: 10.1007/s10729-018-9458-2] [Medline: $\underline{30382448]}$

11. Whitehead L, Seaton P. The effectiveness of self-management mobile phone and tablet apps in long-term condition management: a systematic review. J Med Internet Res 2016 May 16;18(5):e97 [FREE Full text] [doi: 10.2196/jmir.4883] [Medline: 27185295]

12. Bhardwaj NN, Wodajo B, Gochipathala K, Paul DP, Coustasse A. Can mHealth revolutionize the way we manage adult obesity? Perspect Health Inf Manag 2017;14(Spring):1a [FREE Full text] [Medline: 28566984]

13. Wang Y, Min J, Khuri J, Xue H, Xie B, A Kaminsky L, et al. Effectiveness of mobile health interventions on diabetes and obesity treatment and management: systematic review of systematic reviews. JMIR Mhealth Uhealth 2020 Apr 28;8(4):e15400 [FREE Full text] [doi: 10.2196/15400] [Medline: 32343253]

14. Cavero-Redondo I, Martinez-Vizcaino V, Fernandez-Rodriguez R, Saz-Lara A, Pascual-Morena C, Álvarez-Bueno C. Effect of behavioral weight management interventions using lifestyle mHealth self-monitoring on weight loss: a systematic review and meta-analysis. Nutrients 2020 Jul 03;12(7):1977 [FREE Full text] [doi: 10.3390/nu12071977] [Medline: $\underline{32635174]}$

15. Hutchesson MJ, Rollo ME, Krukowski R, Ells L, Harvey J, Morgan PJ, et al. eHealth interventions for the prevention and treatment of overweight and obesity in adults: a systematic review with meta-analysis. Obes Rev 2015 May;16(5):376-392. [doi: 10.1111/obr.12268] [Medline: 25753009]

16. Romeo A, Edney S, Plotnikoff R, Curtis R, Ryan J, Sanders I, et al. Can smartphone apps increase physical activity? Systematic review and meta-analysis. J Med Internet Res 2019 Mar 19;21(3):e12053 [FREE Full text] [doi: 10.2196/12053] [Medline: $\underline{30888321]}$

17. Richardson CR, Newton TL, Abraham JJ, Sen A, Jimbo M, Swartz AM. A meta-analysis of pedometer-based walking interventions and weight loss. Ann Fam Med 2008;6(1):69-77 [FREE Full text] [doi: 10.1370/afm.761] [Medline: 18195317]

18. Chiauzzi E, Rodarte C, DasMahapatra P. Patient-centered activity monitoring in the self-management of chronic health conditions. BMC Med 2015 Apr 09;13:77 [FREE Full text] [doi: 10.1186/s12916-015-0319-2] [Medline: 25889598]

19. Fuller D, Colwell E, Low J, Orychock K, Tobin MA, Simango B, et al. Reliability and validity of commercially available wearable devices for measuring steps, energy expenditure, and heart rate: systematic review. JMIR Mhealth Uhealth 2020 Sep 08;8(9):e18694 [FREE Full text] [doi: 10.2196/18694] [Medline: 32897239]

20. Kirk MA, Amiri M, Pirbaglou M, Ritvo P. Wearable technology and physical activity behavior change in adults with chronic cardiometabolic disease: a systematic review and meta-analysis. Am J Health Promot 2019 Jun;33(5):778-791. [doi: 10.1177/0890117118816278] [Medline: 30586996]

21. Brickwood K, Watson G, O'Brien J, Williams AD. Consumer-based wearable activity trackers increase physical activity participation: systematic review and meta-analysis. JMIR Mhealth Uhealth 2019 Apr 12;7(4):e11819 [FREE Full text] [doi: 10.2196/11819] [Medline: 30977740]

22. Wang JB, Cadmus-Bertram LA, Natarajan L, White MM, Madanat H, Nichols JF, et al. Wearable sensor/device (Fitbit One) and SMS text-messaging prompts to increase physical activity in overweight and obese adults: a randomized controlled trial. Telemed J E Health 2015 Oct;21(10):782-792 [FREE Full text] [doi: 10.1089/tmj.2014.0176] [Medline: 26431257]

23. Schoeppe S, Alley S, Van Lippevelde W, Bray NA, Williams SL, Duncan MJ, et al. Efficacy of interventions that use apps to improve diet, physical activity and sedentary behaviour: a systematic review. Int J Behav Nutr Phys Act 2016 Dec 07;13(1):127 [FREE Full text] [doi: 10.1186/s12966-016-0454-y] [Medline: 27927218]

24. Spring B, Pellegrini C, McFadden HG, Pfammatter AF, Stump TK, Siddique J, et al. Multicomponent mHealth intervention for large, sustained change in multiple diet and activity risk behaviors: the make better choices 2 randomized controlled trial. J Med Internet Res 2018 Jun 19;20(6):e10528 [FREE Full text] [doi: 10.2196/10528] [Medline: 29921561]

25. Duncan M, Fenton S, Brown W, Collins C, Glozier N, Kolt G, et al. Efficacy of a multi-component m-health weight-loss intervention in overweight and obese adults: a randomised controlled trial. Int J Environ Res Public Health 2020 Aug 26;17(17):6200 [FREE Full text] [doi: 10.3390/ijerph17176200] [Medline: 32859100]

26. Patel ML, Wakayama LN, Bennett GG. Self-monitoring via digital health in weight loss interventions: a systematic review among adults with overweight or obesity. Obesity (Silver Spring) 2021 Mar;29(3):478-499. [doi: 10.1002/oby.23088] [Medline: 33624440]

27. Wang Y, Xue H, Huang Y, Huang L, Zhang D. A systematic review of application and effectiveness of mHealth interventions for obesity and diabetes treatment and self-management. Adv Nutr 2017 May;8(3):449-462 [FREE Full text] [doi: 10.3945/an.116.014100] [Medline: 28507010] 
28. Fawcett E, Van Velthoven MH, Meinert E. Long-term weight management using wearable technology in overweight and obese adults: systematic review. JMIR Mhealth Uhealth 2020 Mar 10;8(3):e13461 [FREE Full text] [doi: 10.2196/13461] [Medline: 32154788]

29. Jakicic JM, Davis KK, Rogers RJ, King WC, Marcus MD, Helsel D, et al. Effect of wearable technology combined with a lifestyle intervention on long-term weight loss: the IDEA randomized clinical trial. JAMA 2016 Sep 20;316(11):1161-1171 [FREE Full text] [doi: 10.1001/jama.2016.12858] [Medline: 27654602]

30. Recio-Rodríguez JI, Martín-Cantera C, González-Viejo N, Gómez-Arranz A, Arietaleanizbeascoa MS, Schmolling-Guinovart Y, EVIDENT Group. Effectiveness of a smartphone application for improving healthy lifestyles, a randomized clinical trial (EVIDENT II): study protocol. BMC Public Health 2014 Mar 15;14:254 [FREE Full text] [doi: 10.1186/1471-2458-14-254] [Medline: 24628961]

31. Lugones-Sanchez C, Sanchez-Calavera MA, Repiso-Gento I, Adalia EG, Ramirez-Manent JI, Agudo-Conde C, EVIDENT 3 Investigators. Effectiveness of an mHealth intervention combining a smartphone app and smart band on body composition in an overweight and obese population: randomized controlled trial (EVIDENT 3 study). JMIR Mhealth Uhealth 2020 Nov 26;8(11):e21771 [FREE Full text] [doi: 10.2196/21771] [Medline: 33242020]

32. Recio-Rodriguez JI, Gómez-Marcos MA, Agudo-Conde C, Ramirez I, Gonzalez-Viejo N, Gomez-Arranz A, EVIDENT 3 investigators. EVIDENT 3 Study: a randomized, controlled clinical trial to reduce inactivity and caloric intake in sedentary and overweight or obese people using a smartphone application: study protocol. Medicine (Baltimore) 2018 Jan;97(2):e9633 [FREE Full text] [doi: 10.1097/MD.0000000000009633] [Medline: 29480874]

33. Puig-Ribera A, Martín-Cantera C, Puigdomenech E, Real J, Romaguera M, Magdalena-Belio J, EVIDENT Group. Screening physical activity in family practice: validity of the Spanish version of a brief physical activity questionnaire. PLoS One 2015;10(9):e0136870 [FREE Full text] [doi: 10.1371/journal.pone.0136870] [Medline: 26379036]

34. Voils CI, Olsen MK, Gierisch JM, McVay MA, Grubber JM, Gaillard L, et al. Maintenance of weight loss after initiation of nutrition training: a randomized trial. Ann Intern Med 2017 Apr 04;166(7):463-471 [FREE Full text] [doi:

10.7326/M16-2160] [Medline: 28241185]

35. Jensen MD, Ryan DH, Apovian CM, Ard JD, Comuzzie AG, Donato KA, American College of Cardiology/American Heart Association Task Force on Practice Guidelines, Obesity Society. 2013 AHA/ACC/TOS guideline for the management of overweight and obesity in adults: a report of the American College of Cardiology/American Heart Association Task Force on Practice Guidelines and The Obesity Society. Circulation 2014 Jun 24;129(25 Suppl 2):S102-S138 [FREE Full text] [doi: 10.1161/01.cir.0000437739.71477.ee] [Medline: 24222017]

36. Santiago Pérez M, Hervada Vidal X, Naveira Barbeito G, Silva L, Fariñas H, Vázquez E, et al. El programa epidat: usos y perspectivas. Rev Panam Salud Publica 2010 Jan;27(1):80-82 [FREE Full text] [doi: 10.1590/S1020-49892010000100012]

37. Salas-Salvadó J, Rubio MA, Barbany M, Moreno B, Grupo Colaborativo de la SEEDO. [SEEDO 2007 Consensus for the evaluation of overweight and obesity and the establishment of therapeutic intervention criteria]. Med Clin (Barc) 2007 Feb 10;128(5):184-196. [doi: 10.1016/s0025-7753(07)72531-9] [Medline: 17298782]

38. Krakauer NY, Krakauer JC. A new body shape index predicts mortality hazard independently of body mass index. PLoS One 2012;7(7):e39504 [FREE Full text] [doi: 10.1371/journal.pone.0039504] [Medline: 22815707]

39. Thomas D, Bredlau C, Bosy-Westphal A, Mueller M, Shen W, Gallagher D, et al. Relationships between body roundness with body fat and visceral adipose tissue emerging from a new geometrical model. Obesity (Silver Spring) 2013 Nov;21(11):2264-2271 [FREE Full text] [doi: 10.1002/oby.20408] [Medline: 23519954]

40. Román Viñas B, Ribas Barba L, Ngo J, Serra Majem L. [Validity of the international physical activity questionnaire in the Catalan population (Spain)]. Gac Sanit 2013;27(3):254-257 [FREE Full text] [doi: 10.1016/j.gaceta.2012.05.013] [Medline: 23103093]

41. Jetté M, Sidney K, Blümchen G. Metabolic equivalents (METS) in exercise testing, exercise prescription, and evaluation of functional capacity. Clin Cardiol 1990 Aug;13(8):555-565 [FREE Full text] [doi: 10.1002/clc.4960130809] [Medline: 2204507]

42. Fernández-Ballart JD, Piñol JL, Zazpe I, Corella D, Carrasco P, Toledo E, et al. Relative validity of a semi-quantitative food-frequency questionnaire in an elderly Mediterranean population of Spain. Br J Nutr 2010 Jun;103(12):1808-1816. [doi: 10.1017/S0007114509993837] [Medline: 20102675]

43. Schröder H, Fitó M, Estruch R, Martínez-González MA, Corella D, Salas-Salvadó J, et al. A short screener is valid for assessing Mediterranean diet adherence among older Spanish men and women. J Nutr 2011 Jun;141(6):1140-1145. [doi: 10.3945/jn.110.135566] [Medline: 21508208]

44. ESH/ESC Task Force for the Management of Arterial Hypertension. 2013 Practice guidelines for the management of arterial hypertension of the European Society of Hypertension (ESH) and the European Society of Cardiology (ESC): ESH/ESC task force for the management of arterial hypertension. J Hypertens 2013 Oct;31(10):1925-1938. [doi: 10.1097/HJH.0b013e328364ca4c] [Medline: 24107724]

45. WHO MONICA Project Principal Investigators. The World Health Organization MONICA Project (monitoring trends and determinants in cardiovascular disease): a major international collaboration. J Clin Epidemiol 1988;41(2):105-114. [doi: 10.1016/0895-4356(88)90084-4] [Medline: 3335877] 
46. Raidl M, Rich M, Lanting R, Safaii S. The healthy diabetes plate. J Am Dietetic Assoc 2010 Sep;110(9):A15. [doi: 10.1016/j.jada.2010.06.050]

47. BEDCA. Base de datos Española de composición de alimentos. URL: https://bedca.net/ [accessed 2022-01-11]

48. World Medical Association. World Medical Association Declaration of Helsinki: ethical principles for medical research involving human subjects. JAMA 2013 Nov 27;310(20):2191-2194. [doi: 10.1001/jama.2013.281053] [Medline: 24141714]

49. Greaves CJ, Sheppard KE, Abraham C, Hardeman W, Roden M, Evans PH, IMAGE Study Group. Systematic review of reviews of intervention components associated with increased effectiveness in dietary and physical activity interventions. BMC Public Health 2011 Feb 18;11:119 [FREE Full text] [doi: 10.1186/1471-2458-11-119] [Medline: 21333011]

50. Thomas J, Raynor H, Bond D, Luke A, Cardoso C, Foster G, et al. Weight loss in Weight Watchers Online with and without an activity tracking device compared to control: a randomized trial. Obesity (Silver Spring) 2017 Jun;25(6):1014-1021. [doi: 10.1002/oby.21846] [Medline: 28437597]

51. Kurscheid T, Redaélli M, Heinen A, Hahmann P, Behle K, Froböse I. [App-controlled feedback devices can support sustainability of weight loss. Multicentre QUANT-study shows additional weight loss and gain of QoL via multiple feedback-devices in OPTIFAST®52-program]. Z Psychosom Med Psychother 2019 Sep;65(3):224-238. [doi: 10.13109/zptm.2019.65.3.224] [Medline: 31476994]

52. Painter SL, Ahmed R, Hill JO, Kushner RF, Lindquist R, Brunning S, et al. What matters in weight loss? An in-depth analysis of self-monitoring. J Med Internet Res 2017 May 12;19(5):e160 [FREE Full text] [doi: 10.2196/jmir.7457] [Medline: 28500022]

53. Harvey J, Krukowski R, Priest J, West D. Log often, lose more: electronic dietary self-monitoring for weight loss. Obesity (Silver Spring) 2019 Mar;27(3):380-384 [FREE Full text] [doi: 10.1002/oby.22382] [Medline: 30801989]

54. Waters L, George AS, Chey T, Bauman A. Weight change in control group participants in behavioural weight loss interventions: a systematic review and meta-regression study. BMC Med Res Methodol 2012 Aug 08;12(1):120 [FREE Full text] [doi: 10.1186/1471-2288-12-120] [Medline: 22873682]

55. Füzéki E, Engeroff T, Banzer W. Health benefits of light-intensity physical activity: a systematic review of accelerometer data of the national health and nutrition examination survey (NHANES). Sports Med 2017 Sep;47(9):1769-1793. [doi: 10.1007/s40279-017-0724-0] [Medline: 28393328]

56. Swindell N, Rees P, Fogelholm M, Drummen M, MacDonald I, Martinez JA, et al. Compositional analysis of the associations between 24-h movement behaviours and cardio-metabolic risk factors in overweight and obese adults with pre-diabetes from the PREVIEW study: cross-sectional baseline analysis. Int J Behav Nutr Phys Act 2020 Mar 04;17(1):29 [FREE Full text] [doi: 10.1186/s12966-020-00936-5] [Medline: 32131847]

57. Cadmus-Bertram LA, Marcus BH, Patterson RE, Parker BA, Morey BL. Randomized trial of a Fitbit-based physical activity intervention for women. Am J Prev Med 2015 Sep;49(3):414-418 [FREE Full text] [doi: 10.1016/j.amepre.2015.01.020] [Medline: 26071863]

58. Solbrig L, Jones R, Kavanagh D, May J, Parkin T, Andrade J. People trying to lose weight dislike calorie counting apps and want motivational support to help them achieve their goals. Internet Interv 2017 Mar;7:23-31 [FREE Full text] [doi: 10.1016/j.invent.2016.12.003] [Medline: 28286739]

59. Hu EA, Nguyen V, Langheier J, Shurney D. Weight reduction through a digital nutrition and food purchasing platform among users with obesity: longitudinal study. J Med Internet Res 2020 Sep 02;22(9):e19634 [FREE Full text] [doi: 10.2196/19634] [Medline: 32792332]

60. Pagoto S, Schneider K, Oleski J, Luciani J, Bodenlos J, Whited M. Male inclusion in randomized controlled trials of lifestyle weight loss interventions. Obesity (Silver Spring) 2012 Jun;20(6):1234-1239 [FREE Full text] [doi: 10.1038/oby.2011.140] [Medline: 21633403]

61. French SA, Jeffery RW, Wing RR. Sex differences among participants in a weight-control program. Addict Behav 1994;19(2):147-158. [doi: 10.1016/0306-4603(94)90039-6] [Medline: 8036962]

62. Guertler D, Vandelanotte C, Kirwan M, Duncan MJ. Engagement and nonusage attrition with a free physical activity promotion program: the case of 10,000 steps Australia. J Med Internet Res 2015 Jul 15;17(7):e176 [FREE Full text] [doi: 10.2196/jmir.4339] [Medline: 26180040]

63. Cheatham SW, Stull KR, Fantigrassi M, Motel I. The efficacy of wearable activity tracking technology as part of a weight loss program: a systematic review. J Sports Med Phys Fitness 2018 Apr;58(4):534-548. [doi: 10.23736/S0022-4707.17.07437-0] [Medline: 28488834]

64. Elavsky S, Smahel D, Machackova H. Who are mobile app users from healthy lifestyle websites? Analysis of patterns of app use and user characteristics. Transl Behav Med 2017 Dec;7(4):891-901 [FREE Full text] [doi: 10.1007/s13142-017-0525-x] [Medline: 28929368]

65. Moroshko I, Brennan L, O'Brien P. Predictors of dropout in weight loss interventions: a systematic review of the literature. Obes Rev 2011 Nov;12(11):912-934. [doi: 10.1111/j.1467-789X.2011.00915.x] [Medline: 21815990]

66. Kozak AT, Buscemi J, Hawkins MA, Wang ML, Breland JY, Ross KM, et al. Technology-based interventions for weight management: current randomized controlled trial evidence and future directions. J Behav Med 2017 Feb;40(1):99-111 [FREE Full text] [doi: 10.1007/s10865-016-9805-z] [Medline: 27783259] 
67. Laing BY, Mangione CM, Tseng C, Leng M, Vaisberg E, Mahida M, et al. Effectiveness of a smartphone application for weight loss compared with usual care in overweight primary care patients: a randomized, controlled trial. Ann Intern Med 2014 Nov 18;161(10 Suppl):S5-12 [FREE Full text] [doi: 10.7326/M13-3005] [Medline: 25402403]

68. Moustgaard H, Clayton GL, Jones HE, Boutron I, Jørgensen L, Laursen DR, et al. Impact of blinding on estimated treatment effects in randomised clinical trials: meta-epidemiological study. BMJ 2020 Jan 21;368:16802 [FREE Full text] [doi: 10.1136/bmj.16802] [Medline: 31964641]

69. Dumville JC, Torgerson DJ, Hewitt CE. Reporting attrition in randomised controlled trials. BMJ 2006 Apr 22;332(7547):969-971 [FREE Full text] [doi: 10.1136/bmj.332.7547.969] [Medline: 16627519]

\author{
Abbreviations \\ APISAL: Primary Care Research Unit of Salamanca \\ CG: control group \\ IBSAL: Biomedical Research Institute of Salamanca \\ IG: intervention group \\ IPAQ-SF: International Physical Activity Questionnaire-Short Form \\ LPA: light physical activity \\ MET: metabolic equivalent \\ mHealth: mobile health \\ REDIAPP: Network for Preventive Activity and Health Promotion
}

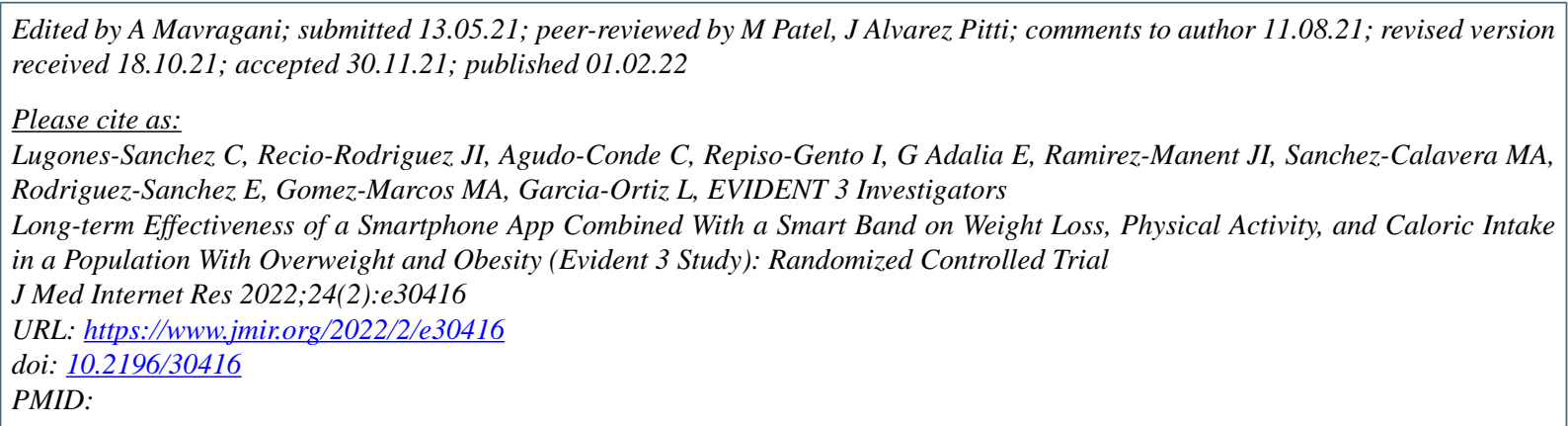

(C) Cristina Lugones-Sanchez, Jose I Recio-Rodriguez, Cristina Agudo-Conde, Irene Repiso-Gento, Esther G Adalia, José Ignacio Ramirez-Manent, Maria Antonia Sanchez-Calavera, Emiliano Rodriguez-Sanchez, Manuel A Gomez-Marcos, Luis Garcia-Ortiz, EVIDENT 3 Investigators. Originally published in the Journal of Medical Internet Research (https://www.jmir.org), 01.02.2022. This is an open-access article distributed under the terms of the Creative Commons Attribution License (https://creativecommons.org/licenses/by/4.0/), which permits unrestricted use, distribution, and reproduction in any medium, provided the original work, first published in the Journal of Medical Internet Research, is properly cited. The complete bibliographic information, a link to the original publication on https://www.jmir.org/, as well as this copyright and license information must be included. 